\title{
Hydroxyapatite Formation in a Single-Stage Anammox-Based Batch Treatment System: Reactor Performance, Phosphorus Recovery, and Microbial Community
}

\author{
Albert Magrí,* Emma Company, Frederic Gich, and Jesús Colprim \\ Cite This: ACS Sustainable Chem. Eng. 2021, 9, 2745-2761 \\ Read Online
}

ACCESS | Wlll Metrics \& More | 期 Article Recommendations

| S1 Supporting Information

ABSTRACT: Simultaneous ammonium-nitrogen $\left(\mathrm{NH}_{4}{ }^{+}-\mathrm{N}\right)$ removal and orthophosphate-phosphorus $\left(\mathrm{PO}_{4}-\mathrm{P}\right)$ biomineralization was studied in two granular sludge sequencing batch reactors treating urban sidestream centrate through the one-stage partial nitritation-anaerobic ammonium oxidation (anammox) process. By adding an external source of calcium, concomitant conversion rates of up to $0.32 \mathrm{~g} \mathrm{NH}_{4}{ }^{+}-\mathrm{N} /(\mathrm{L} \cdot$ days $)$ and $12 \mathrm{mg}$ $\mathrm{PO}_{4}-\mathrm{P} /(\mathrm{L}$-days $)$ were measured while reaching water-phase removal efficiencies of ca. $80 \%$ of the $\mathrm{NH}_{4}{ }^{+}-\mathrm{N}$ and $70 \%$ of the $\mathrm{PO}_{4}-\mathrm{P}$ loaded. The mineral cores formed inside the granules were mostly composed of hydroxyapatite (HAP), which is a recoverable phosphate salt. Yet, the high mineralization of the sludge and its excessive purge from the bioreactor limited the microbial activity in

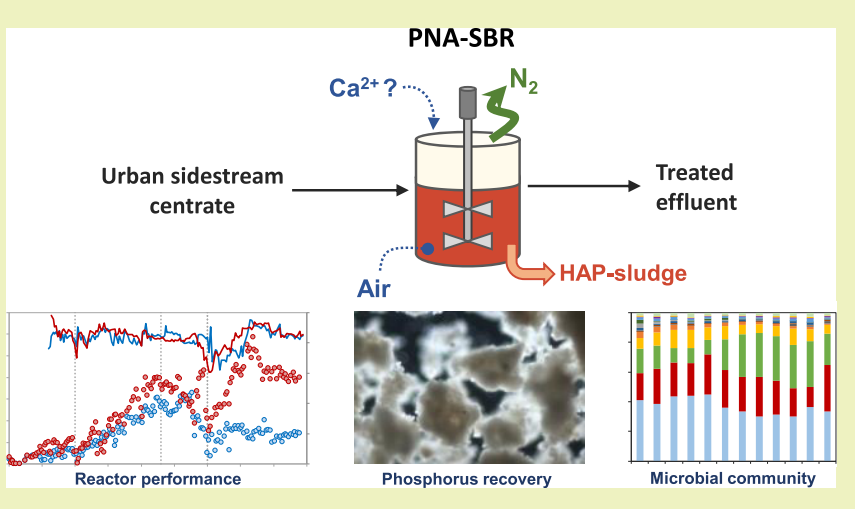
the long term. In this sense, the densest granules, accumulated at the bottom of the bioreactor, were the most susceptible to being harvested because they were the richest in HAP, but at the same time, they contained the highest percentages of anammox bacteria. KEYWORDS: calcium phosphate, precipitated phosphate salt, deammonification, digester supernatant, high-throughput sequencing, Ca. Kuenenia stuttgartiensis

\section{INTRODUCTION}

Phosphorus $(\mathrm{P})$ is an essential element for all living organisms. This nutrient is absolutely necessary for sustaining agri-food production, and its demand rises alongside the growth of the global population. ${ }^{1}$ Currently, mined phosphate rock (i.e., apatite-type ores) is the primary source of $\mathrm{P}$, but this is a finite resource, which is unevenly distributed around the world. ${ }^{2}$ The European Union (EU) depends on the import of $\mathrm{P}$, and it has identified phosphate rock and $\mathrm{P}$ as 2 of the 27 critical raw materials having high importance to the EU economy and having a high risk associated with their supply. ${ }^{3}$

The discharge of improperly treated sewage and $\mathrm{P}$ excess into aquatic ecosystems causes the deterioration of water quality due to the proliferation of algae and eutrophication. ${ }^{4}$ Otherwise, according to the circular economy paradigm, wastewater is a renewable source of $\mathrm{P}$, available at the local scale. Hence, wastewater treatment offers a good opportunity to exploit new ways to produce P-related feedstock aiming at a more sustainable development while preventing pollution. Different methods can be applied in wastewater treatment plants (WWTPs) to achieve P recovery (e.g., crystallization from sewage and internal aqueous streams, extraction from sludge using wet-chemical techniques, transformation from ashes or biochar produced from sludge thermal processing, etc.). ${ }^{5}$ Among them, the crystallization and precipitation of low-soluble salts are commonly used, based on the combination of the dissolved orthophosphate $\left(\mathrm{PO}_{4}\right)$ with a metal ion, e.g., calcium ( $\mathrm{Ca})$, magnesium $(\mathrm{Mg})$, or iron $(\mathrm{Fe})$. Broadly, in view of biological treatment, phosphate precipitation can be accomplished according to upstream, concomitant, or downstream strategies. ${ }^{6}$ Regarding the product finally obtained, magnesium phosphates (MgP) such as struvite (magnesium ammonium phosphate (MAP)) are frequently considered as an efficient slow-release fertilizer for crops, whereas calcium phosphates $(\mathrm{CaP})$ such as hydroxyapatite (HAP) offer broader industrial applications beyond fertilizers since the composition is similar to mined phosphate rock. ${ }^{8}$ The equation for the crystallization of $\operatorname{HAP}\left(\mathrm{Ca}_{10}\left(\mathrm{PO}_{4}\right)_{6}(\mathrm{OH})_{2}\right)$, a mineral containing $18.5 \mathrm{wt} \% \mathrm{P}$, is as follows: (eq 1$)^{9}$

$$
10 \mathrm{Ca}^{2+}+6 \mathrm{PO}_{4}^{3-}+2 \mathrm{OH}^{-} \rightarrow \mathrm{Ca}_{10}\left(\mathrm{PO}_{4}\right)_{6}(\mathrm{OH})_{2}
$$

Received: November 3, 2020

Revised: January 19, 2021

Published: February 9, 2021 
Owing to the significant enhancement in the energy balance achievable with respect to other conventional biotechnologies, completely autotrophic nitrogen $(\mathrm{N})$ removal (i.e., the partial nitritation-anammox (PNA) process) is an appealing alternative for treating the $\mathrm{N}$-rich sidestream centrates produced in urban WWTPs. ${ }^{10}$ This process is based on the coupling of partial nitritation (PN), targeting partial aerobic ammonium $\left(\mathrm{NH}_{4}^{+}\right)$oxidation to nitrite $\left(\mathrm{NO}_{2}{ }^{-}\right)$without nitrate formation $\left(\mathrm{NO}_{3}{ }^{-}\right)$(eq 2$),{ }^{11}$ and anaerobic ammonium oxidation (anammox, A), in which ammonium and nitrite are converted in the absence of oxygen to dinitrogen gas $\left(\mathrm{N}_{2}\right)$ with small nitrate production (eq 3 ). ${ }^{12}$

$$
\begin{aligned}
& 1 \mathrm{NH}_{4}{ }^{+}+0.803 \mathrm{O}_{2}+0.042 \mathrm{CO}_{2}+0.01 \mathrm{HCO}_{3}{ }^{-} \\
& \rightarrow 0.42 \mathrm{NH}_{4}^{+}+0.57 \mathrm{NO}_{2}{ }^{-}+0.01 \mathrm{C}_{5} \mathrm{H}_{7} \mathrm{O}_{2} \mathrm{~N} \\
& +0.56 \mathrm{H}_{2} \mathrm{O}+1.14 \mathrm{H}^{+} \\
& 1 \mathrm{NH}_{4}^{+}+1.32 \mathrm{NO}_{2}^{-}+0.066 \mathrm{HCO}_{3}^{-}+0.13 \mathrm{H}^{+} \\
& \rightarrow 1.02 \mathrm{~N}_{2}+0.26 \mathrm{NO}_{3}{ }^{-}+0.066 \mathrm{CH}_{2} \mathrm{O}_{0.5} \mathrm{~N}_{0.15} \\
& +2.03 \mathrm{H}_{2} \mathrm{O}
\end{aligned}
$$

The sidestream centrate obtained after centrifuging anaerobically digested sludge for its dewatering contains low levels of biodegradable organic carbon. If no treatment is considered, then this centrate is returned back to the headworks of the WWTP, contributing in a small proportion to the flow entering the plant, but to a larger extent to the amount of nutrients loaded in the mainstream. The PNA-based treatment of this centrate favors the energy self-sufficiency of the WWTP, mostly because of the diminished energy demand for aeration and the feasibility for increasing the recovery of renewable energy in the form of biogas through anaerobic digestion. Its application, thus, can help in reducing the environmental impact and in improving sustainability in wastewater treatment. ${ }^{13,14}$ In this context, the PNA process is frequently engineered in single-stage systems ${ }^{15}$ according to eq 4 (biomass not included). Granular sludge sequencing batch reactors (SBRs) are commonly considered, running under oxygen $\left(\mathrm{O}_{2}\right)$ mass transfer limitation due to low-intensity aeration. Oxygen is a substrate for nitritation but also inhibits reversibly the anammox process. This fact makes aeration control of primary importance to maximize the $\mathrm{N}$-removal rate and efficiency ${ }^{16}$ owing to the delicate equilibrium existing between both bioprocesses, with minimal nitritation (i.e., aerobic nitrite oxidation to nitrate). Aerobic ammoniumoxidizing bacteria (AOB) are supposed to be the dominant microorganisms in the outer layer of the granules, whereas anammox bacteria (AnAOB) dominate the inner part. Such a microbial distribution results in a local $\mathrm{pH}$-value gradient along the granule radius, with higher $\mathrm{pH}$ values in the core. ${ }^{19}$ Alkalinity consumption (i.e., mostly comprising the inorganic carbon system) and $\mathrm{pH}$-value diminution (acidification) in the bulk liquid are other collateral consequences of the PNA process. These parameters play a primary role when targeting phosphate precipitation.

$$
\begin{aligned}
1 \mathrm{NH}_{4}^{+}+0.86 \mathrm{O}_{2} \rightarrow & 0.44 \mathrm{~N}_{2}+0.11 \mathrm{NO}_{3}{ }^{-}+1.45 \mathrm{H}_{2} \mathrm{O} \\
& +1.08 \mathrm{H}^{+}
\end{aligned}
$$

Biologically induced phosphate mineralization has already been proposed as a promising alternative for recovering $\mathrm{P}$ from sidestream centrate, either as $\mathrm{MgP}^{18}$ or as $\mathrm{CaP}{ }^{19,20}$ Biomediated precipitation involves the reaction between extracellular ions and metabolic products released across or into the cell wall. Recent works integrating anammox and CaPprecipitation reactions evidenced the feasibility of the formation of a dense HAP core wrapped by an external biofilm. $^{21,22}$ As a consequence, a highly mineralized sludge is produced within the bioreactor. Once this sludge is harvested, the high $\mathrm{P}$ content makes it an interesting resource for subsequent valorization. Specifically using a single-stage PNA granular system, Johansson et al. ${ }^{19}$ (SBR at $25^{\circ} \mathrm{C}$ ) treated real urban sidestream centrate under loading rates of $0.31 \mathrm{~g} \mathrm{~N} /(\mathrm{L}$. days) and $18 \mathrm{mg} \mathrm{P} /(\mathrm{L} \cdot$ days $)$, achieving $66 \% \mathrm{~N}$ removal and HAP crystallization without adding chemicals; more recently, Guo and $\mathrm{Li}^{23}$ (airlift reactor at $25{ }^{\circ} \mathrm{C}$ ) worked with synthetic wastewater reaching $\mathrm{N}$-removal rates as high as $1.2 \mathrm{~g} \mathrm{~N} /(\mathrm{L}$. days) and $83 \%$ P removal from water. Similar to the anammox systems described above, local gradients of $\mathrm{pH}$ value and constituent ion concentration have also been described as the driving forces triggering the enrichment of $\mathrm{CaP}$ in granules from other aerobic ${ }^{24}$ and anaerobic ${ }^{25}$ wastewater treatment applications.

Following the previous work on this topic carried out by the LEQUIA research group, ${ }^{19}$ the objective of this study is to obtain further insights into simultaneous $\mathrm{N}$ removal through the PNA process and $\mathrm{P}$ mineralization by HAP crystallization. To do so, two PNA SBRs have been operated in parallel processing real urban sidestream centrate. Particularly, the focus of this study is the analysis of the appropriate conditions favoring the performance of the process, including the supply of an external source of $\mathrm{Ca}$ for enhancing $\mathrm{P}$ recovery. To characterize the evolution of the microbial community involved in such a process, the dynamics of the prokaryotes growing within the granular bioreactors is analyzed by $16 \mathrm{~S}$ ribosomal ribonucleic acid (rRNA) gene high-throughput sequencing.

\section{MATERIALS AND METHODS}

Sludge Source. The sludge used as inoculum was collected from a full-scale leachate treatment plant in a landfill site (CORSA, Reus, Spain). This facility uses a two-stage system that consists of two SBRs connected in series, where PN and anammox are operated individually. ${ }^{26}$ On the sampling day, the leachate being processed was characterized as follows: $\mathrm{pH}, 8.3$; conductivity, $35 \mathrm{mS} / \mathrm{cm}$; alkalinity, $7.8 \mathrm{~g} \mathrm{CaCO}_{3} / \mathrm{L}$; chemical oxygen demand, $4.1 \mathrm{~g} \mathrm{O}_{2} / \mathrm{L}$; and $\mathrm{NH}_{4}{ }^{+}, 1.6 \mathrm{~g} \mathrm{~N} / \mathrm{L}$. Mixed liquors from both bioreactors (which were running at ca. $30{ }^{\circ} \mathrm{C}$ ) were collected separately and, after arriving at the lab, blended together in two twin SBRs at a PN/anammox ratio of 5:10 L. After allowing the sludge to settle, and subsequent supernatant withdrawal, the final reactor volume was adjusted to $10 \mathrm{~L}$, resulting in a total suspended solids (TSS) content of $0.88 \mathrm{~g} / \mathrm{L}$ (98\% as volatile suspended solids, VSS). At this point, both bioreactors started running cyclically.

Urban Sidestream Centrate. The urban sidestream centrate was collected after centrifugation at Terri WWTP (Cornellà de Terri, Catalonia, Spain) regularly every 3-4 weeks for a period longer than 1 year. After arriving at the lab, before its final storage and further processing, the centrate was naturally decanted for about 1 day to discard the eventual presence of suspended solids. A detailed characterization of this decanted centrate is given in Table S1.

Experimental Setup and Operational Conditions Applied. The single-stage PNA process was operated in two SBRs running in parallel, named SBR1 and SBR2, for approximately 15 months (from December 2018 to February 2020). Further details about the experimental setup, which was modified after Johansson et al., ${ }^{19}$ are 
Table 1. Process Performance in the PNA SBRs throughout the Experimental Period ${ }^{a}$

\begin{tabular}{|c|c|c|c|c|c|c|c|c|}
\hline \multirow[b]{2}{*}{ parameter } & \multicolumn{2}{|c|}{ phase I } & \multicolumn{2}{|c|}{ phase II } & \multicolumn{2}{|c|}{ phase III } & \multicolumn{2}{|c|}{ phase IV } \\
\hline & SBR1 & SBR2 & SBR1 & SBR2 & SBR1 & SBR2 & SBR1 & SBR2 \\
\hline time length (days) & 100 & & 130 & & 70 & & 140 & \\
\hline aeration $\left(\mathrm{L}_{\text {air }} /(\mathrm{L} \cdot\right.$ days $\left.)\right)$ & $3-7$ & $2-8$ & $5-40$ & $6-27$ & $14-40$ & $20-26$ & $7-27$ & $8-42$ \\
\hline oxic reaction time (\% of cycle) & $73-83$ & $73-83$ & $73-88$ & $73-88$ & 89 & 89 & $61-82$ & $80-89$ \\
\hline hydraulic residence time (days) & $\geq 11.4$ & $\geq 7.4$ & $2.9-17$ & $2.2-25$ & $2.2-4.9$ & $1.4-3.2$ & $3.1-13.7$ & $1.4-2.9$ \\
\hline metal ion addition ${ }^{b}(\mathrm{mg} /(\mathrm{L} \cdot$ days $))$ & 0 & 0 & 0 & 0 & $0-38$ & $21-73$ & $0-24$ & 0 \\
\hline $\mathrm{N}$ loading rate $\left(\mathrm{g} \mathrm{NH}_{4}^{+}-\mathrm{N} /(\mathrm{L} \cdot\right.$ days $\left.)\right)$ & $0-0.09$ & $0-0.13$ & $0.06-0.35$ & $0.05-0.48$ & $0.17-0.40$ & $0.27-0.53$ & $0.06-0.25$ & $0.28-0.62$ \\
\hline $\mathrm{P}$ loading rate $\left(\mathrm{mg} \mathrm{PO}_{4}-\mathrm{P} /(\mathrm{L} \cdot\right.$ days $\left.)\right)$ & $0-6$ & $0-2$ & $1-46^{c}$ & $1-24$ & $8-23$ & $9-34$ & $3-12$ & $8-32$ \\
\hline $\mathrm{N}$ conversion efficiency $\left(\%\right.$ of $\left.\mathrm{NH}_{4}^{+}\right)$ & $67-96$ & $63-99$ & $78-91$ & $71-92$ & $80-89$ & $72-86$ & $66-94$ & $61-93$ \\
\hline P-uptake efficiency (PUE) (\% of $\left.\mathrm{PO}_{4}\right)$ & n.d. ${ }^{d}$ & n.d. & $0-45$ & n.d. & $32-83$ & n.d. & $46-88$ & n.d. \\
\hline $\begin{array}{l}\text { specific } \mathrm{N} \text { conversion rate } \\
\left(\mathrm{mg} \mathrm{NH}^{+}-\mathrm{N} /(\mathrm{g} \text { VSS. davs })\right)\end{array}$ & $22-51$ & $22-84$ & $60-116$ & $69-148$ & $62-102$ & $101-115$ & $45-83$ & $86-135$ \\
\hline
\end{tabular}

${ }^{a}$ Reported values are means of the three closest values available in the experimental phase being characterized. ${ }^{b}$ Metal ions added in the bioreactors: $\mathrm{Ca}^{2+}$ in SBR1 and $\mathrm{Mg}^{2+}$ in SBR2. ${ }^{c}$ An external chemical phosphate source was added to the centrate used as feeding in SBR1 in phase II. ${ }^{d}$ n.d.: not detected.

given in the Supporting Information. The process temperature was controlled at $25 \pm 2{ }^{\circ} \mathrm{C}$. Air was supplied through a solenoid valve and a gas mass flow controller (targeted airflow rate selected manually). As an additional safety factor, air supply was momentarily interrupted if the concentration of dissolved oxygen in the bulk liquid exceeded a set-point value (typically $0.3 \mathrm{mg} \mathrm{O}_{2} / \mathrm{L}$ ). The bioreactors ran according to cycles lasting $6 \mathrm{~h}$ throughout the experimental period, resulting in four cycles per day. However, different feeding strategies, external reagent supplies, and operational parameter values were considered during this time. The experimental period was divided into four different phases: phase I (days $0-100,100$ days), phase II (days 101-230, 130 days), phase III (days 231-300, 70 days), and phase IV (days 301-440, 140 days). In phase I (startup of the PNA process) and phase II (consolidation of the PNA process), one working cycle was scheduled as 9-10 repeated sequences of aerated feeding and reaction (each individual sequence lasting 29$31.5 \mathrm{~min}$ ), followed by an anoxic reaction period $(35-89 \mathrm{~min})$, settling $(15 \rightarrow 5 \mathrm{~min})$, and withdrawn $(5 \mathrm{~min})$. The absence of nitrite accumulation in the SBRs was verified by the end of a cycle on a daily basis by means of a ready-to-use kit. Increases in the airflow rate, and in the $\mathrm{N}$ loading rate (NLR) applied, were decided individually according to the fulfillment of this criterion. The NLR was raised by increasing the feeding pump inflow rate, or by lengthening the feeding, while maintaining constant the total length of each aerobic sequence. The $\mathrm{pH}$ within the bioreactors was only monitored, freely evolving according to the running conditions (7.0-7.8), but not controlled to a given set-point. A synthetic source of $P$ (i.e., phosphate solution) was added to the centrate fed to SBR1 to increase the phosphate loading rate (PLR) applied. In phase III (cation supply to induce $\mathrm{P}$ precipitation), the configuration of the aerated periods (including feeding and reaction) was switched from a fixed-time schedule without $\mathrm{pH}$ control to a $\mathrm{pH}$-based dynamic autoregulation. Moreover, a synthetic source of a metal cation was directly added to the SBRs at the beginning of the cycle by means of an additional pump (i.e., added by drip from the top of the bioreactor during the first $3 \mathrm{~min}$ of the cycle). The cation added to SBR1 was $\mathrm{Ca}^{2+}$ (i.e., $\mathrm{CaCl}_{2}$ solution) according to an increase in the supplied $\mathrm{Ca} / \mathrm{P}$ molar ratio from 2.3 (Table $\mathrm{S} 1$ ) to a mean value of 3.8. The cation added to $\mathrm{SBR} 2$ was $\mathrm{Mg}^{2+}$ (i.e., $\mathrm{MgCl}_{2}$ solution) according to an increase in the supplied $\mathrm{Mg} / \mathrm{P}$ molar ratio from 0.8 (Table S1) to a mean value of 2.3. By the end of this phase, granules $>1 \mathrm{~mm}$ that accumulated at the bottom of the SBR1 were harvested using a sieve. Finally, in phase IV (simultaneous long-term PNA and HAP precipitation), only $\mathrm{Ca}^{2+}$ continued to be added to SBR1, interrupting the $\mathrm{Mg}^{2+}$ supply to SBR2. Several $\mathrm{pH}$ set-point values were applied within the range 7.07.5.

Chemical Analysis, Biological Tests, and Calculations. Offline $\mathrm{pH}$ and electrical conductivity (EC) referred to $25{ }^{\circ} \mathrm{C}$ were measured with a pH-meter (mod. pH-Meter Basic 20+, Crison
Instruments SA, Spain) and a conductimeter (EC-Meter Basic 30+, Crison Instruments SA), respectively. The TSS were determined gravimetrically after sample filtration and drying to constant weight at $105{ }^{\circ} \mathrm{C}$, and the VSS were measured after further ignition in a muffle furnace at $550{ }^{\circ} \mathrm{C}$. The concentrations of the soluble cations, i.e., ammonium $\left(\mathrm{NH}_{4}^{+}\right)$, sodium $\left(\mathrm{Na}^{+}\right)$, potassium $\left(\mathrm{K}^{+}\right)$, magnesium $\left(\mathrm{Mg}^{2+}\right)$, and calcium $\left(\mathrm{Ca}^{2+}\right)$, as well as the concentrations of the soluble anions, i.e., nitrite $\left(\mathrm{NO}_{2}{ }^{-}\right)$, nitrate $\left(\mathrm{NO}_{3}{ }^{-}\right)$, chloride $\left(\mathrm{Cl}^{-}\right)$, sulfate $\left(\mathrm{SO}_{4}{ }^{2-}\right)$, and phosphate $\left(\mathrm{PO}_{4}{ }^{3-}\right)$, were all determined using ion chromatography (mod. ICS-5000, Dionex), after filtering samples with $0.2 \mu \mathrm{m}$ nylon filters. The sludge volume index (SVI) was measured in a $1 \mathrm{~L}$ graduated cylinder using mixed liquor sampled from the bioreactors at the beginning of a new cycle. The height of the sludge was recorded at different times within an interval of 3-30 min. Thus, the $\mathrm{SVI}_{5}$ and $\mathrm{SVI}_{30}$ were the sludge heights at 5 and 30 min, respectively, per gram of TSS. Before analysis through X-ray diffraction (XRD) (mod. D8 Quest Eco, Bruker), the granular sludge was rinsed with Milli- $Q$ water, filtered, dried, and ground. The chemical composition of this sludge $(\mathrm{P}, \mathrm{Ca}, \mathrm{Mg}$, and $\mathrm{K}$ ) was determined by inductively coupled plasma-optical emission spectrometry (ICP-OES) (mod. 5100, Agilent Technologies). Other metals, i.e., arsenic (As), cadmium $(\mathrm{Cd})$, chromium $(\mathrm{Cr})$, copper $(\mathrm{Cu})$, iron $(\mathrm{Fe})$, lead $(\mathrm{Pb})$, mercury $(\mathrm{Hg})$, nickel $(\mathrm{Ni})$, and zinc $(\mathrm{Zn})$, were determined using inductively coupled plasma-mass spectrometry (ICP-MS) (mod. 7500c, Agilent Technologies). The morphology of the granules was qualitatively observed with a stereomicroscope (Stereo Discovery V12, Zeiss), whereas the particle size distribution was studied with a laser diffraction particle size analyzer (LS 13 320, Beckman Coulter), suitable for particle size measurement ranges from 0.040 to $2000 \mu \mathrm{m}$.

Nitrogen conversion in the bioreactors was calculated taking into account the concentration of ammonium, nitrite, and/or nitrate in the influent and effluent water lines, as well as the bioreactor working volume and the volumetric flow rate applied. When necessary, results were referred to the suspended solids content in the bioreactor bulk. Short-term specific anammox activity tests were conducted in batch (in duplicates), taking water samples at regular time intervals for subsequent chemical analysis. The supersaturation conditions for particular phosphate mineral phases, i.e., HAP, octacalcium phosphate (OCP, $\mathrm{Ca}_{8} \mathrm{H}_{2}\left(\mathrm{PO}_{4}\right)_{6} \cdot 5 \mathrm{H}_{2} \mathrm{O}$ ), tricalcium phosphate (TCP, $\left.\mathrm{Ca}_{3}\left(\mathrm{PO}_{4}\right)_{2}\right)$, and MAP $\left(\mathrm{MgNH}_{4} \mathrm{PO}_{4} \cdot 6 \mathrm{H}_{2} \mathrm{O}\right)$, were assessed through the saturation index $\left(\mathrm{SI}, \log _{10}\left(\mathrm{IAP} / K_{\mathrm{sp}}\right)\right)$, as a function of the ion activity product (IAP) of the constituent ions and the solubility product constant $\left(K_{\mathrm{sp}}\right)$ of the mineral phase, using the freeware Visual MINTEQ (ver. 3.1). ${ }^{27}$ More details regarding this section are given in the Supporting Information.

Microbial Community Analysis by High-Throughput Sequencing. Sludge samples from both bioreactors were collected from the solids' sampling tap (Figure S1) once per month during the first 

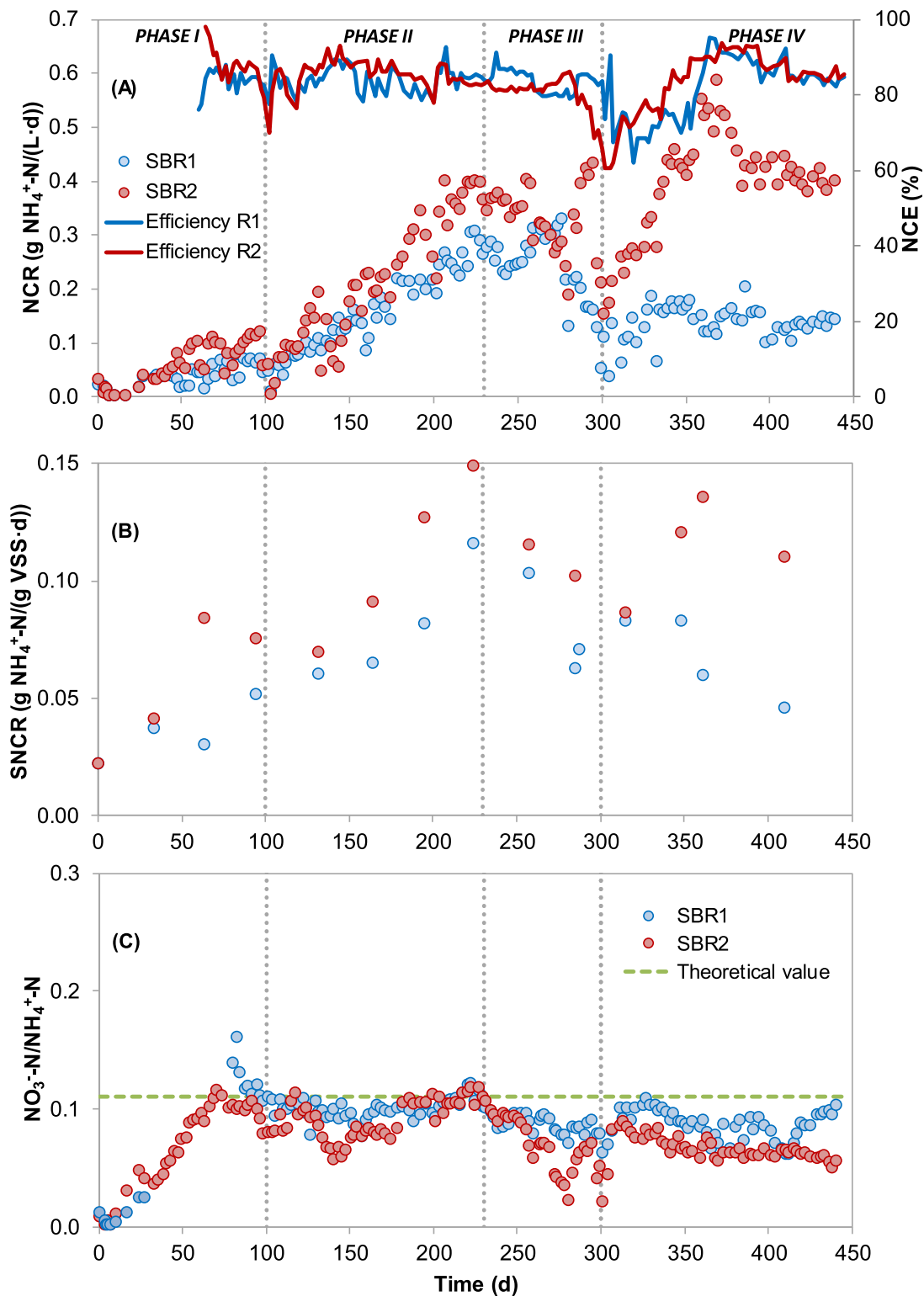

Figure 1. Evolution of the $\mathrm{N}$ conversion rate (NCR) and N conversion efficiency (NCE) (A), the biomass specific NCR (SNCR) (B), and the nitrate-produced-to-ammonium-converted ratio (C) in both bioreactors. The theoretical value was assumed as $0.11 \mathrm{~mol} / \mathrm{mol}(\mathrm{see}$ eq 4 ).

12 months of the experiment to assess the microbial community dynamics. More details regarding the microbial community analysis are given in the Supporting Information. Raw sequence data obtained in this study was deposited at the National Center for Biotechnology Information (NCBI) sequence read archive (SRA) under accession number SUB8280136 and with links to the BioProject database (www.ncbi.nlm.nih.gov/bioproject/) under accession number PRJNA668517.

\section{RESULTS AND DISCUSSION}

Performance of Bioreactors. Nitrogen in the Bulk Liquid. The main parameters characterizing the performance of both PNA SBRs during the four operational phases described above (440 days in total) are shown in Table 1 and Figure $1 \mathrm{~A}-\mathrm{C}$. In phase $\mathrm{I}$, the growth of the granular sludge needed time to consolidate due to the new imposed working conditions and influent wastewater composition, i.e., merging of the seeding sludge coming from two independent full-scale bioreactors into only one lab-scale bioreactor and replacement of the landfill leachate by urban centrate as the feeding stream, which entailed significant differences in terms of composition and EC (from ca. 35 to $9 \mathrm{mS} / \mathrm{cm}$ ). In phase II, a progressive increase of the biological activity was achieved-maximum $\mathrm{N}$ conversion rates (NCRs) reached by the end of this phase were 0.30 and $0.40 \mathrm{~g} \mathrm{NH}_{4}^{+}-\mathrm{N} /(\mathrm{L} \cdot$ days $)$ in SBR1 and SBR2, respectively-pushed by the gradual intensification of the aeration rate. The $\mathrm{N}$ conversion efficiencies (NCEs) in this phase averaged similarly, i.e., $84 \pm 3 \%$ in SBR1 and $85 \pm 4 \%$ in SBR2.

In phase III, the addition of a metal ion into the bioreactors did not cause major disturbances during the first part of this phase. In SBR1 (where $\mathrm{Ca}^{2+}$ was added), concomitant rates for $\mathrm{N}$ conversion and $\mathrm{P}$ uptake (PUR) were estimated up to $0.32 \mathrm{~g}$ $\mathrm{NH}_{4}{ }^{+}-\mathrm{N} /(\mathrm{L} \cdot$ days $)$ and $12 \mathrm{mg} \mathrm{PO}_{4}-\mathrm{P} /(\mathrm{L} \cdot$ days $)$. On day 285, the purge of the largest granules from SBR1 (7 $\mathrm{g}$ of VSS; equivalent to $19 \%$ of the total amount of VSS available), together with an intensive maintenance campaign carried out in the experimental setup, caused a drop in the biological activity down to roughly a half. The previous activity achieved 


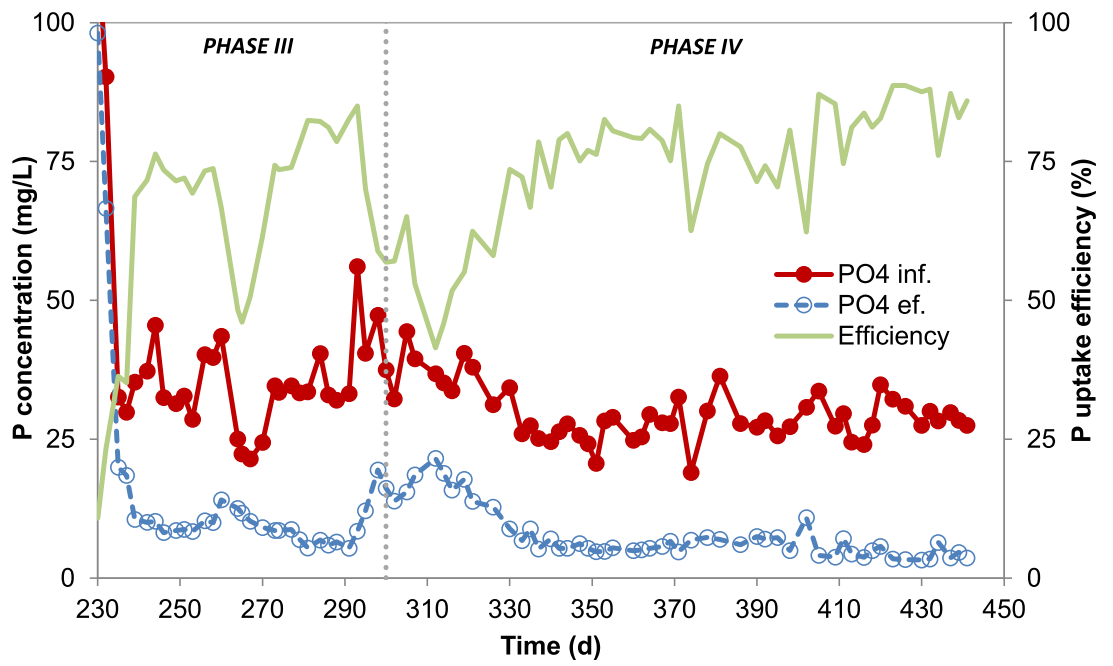

Figure 2. Evolution of the phosphate uptake efficiency in SBR1 while adding $\mathrm{Ca}^{2+}$ (phases III and IV).

in this bioreactor was no longer recovered. On the other hand, in SBR2 (where $\mathrm{Mg}^{2+}$ was added), higher NCRs were measured initially but without the occurrence of $\mathrm{P}$ uptake, similar to that in the previous phase. The maintenance tasks mentioned above also impacted negatively the process performance. Nonetheless, a detrimental effect of $\mathrm{Mg}^{2+}$ addition had already been identified a few days before, which will be further discussed later on. Thus, after the initial drop in the biological activity, it progressively recovered in the following weeks, after interrupting the addition of $\mathrm{Mg}^{2+}$ and readjusting the aeration rate applied. Values below the expected ones for the PNA process (i.e., $0.11 \mathrm{~mol} / \mathrm{mol}$, as shown in eq 4) were confirmed for the nitrate-produced-toammonium-converted ratio in both bioreactors, and thus, a slight concomitant heterotrophic denitrification could have been occurring in these systems (favored by the occurrence of cell lysis).

Finally, in phase IV, the NCRs reached were clearly higher in SBR2 (i.e., the maximum measured value was $0.56 \mathrm{~g} \mathrm{NH}_{4}^{+}-$ $\mathrm{N} /(\mathrm{L} \cdot$ days $)$ ) than in SBR1 (i.e., the maximum value in this case was $0.18 \mathrm{~g} \mathrm{NH}_{4}^{+}-\mathrm{N} /(\mathrm{L} \cdot$ days $\left.)\right)$. Dependence of the NCE with respect to the $\mathrm{pH}$ set-point was confirmed. Thus, the lower the $\mathrm{pH}$ set-point value fixed, the higher the NCE attained. As an example, in SBR1, the NCE averaged $72 \pm 4$, $84 \pm 1$, and $91 \pm 2 \%$ in those time intervals when the $\mathrm{pH}$ setpoints were fixed at 7.5 (days: $312-351$ ), 7.3 (days: $411-$ 440), and 7.0 (days: 364-392), respectively. The switch in the $\mathrm{pH}$ set-point value did not imply major changes either in the NCR or in the P-uptake efficiency (PUE).

Phosphorus in the Bulk Liquid. According to the evolution of the concentrations measured in the water line, and favored by the high $\mathrm{Ca} / \mathrm{Mg}$ molar ratio in the centrate (average: 3.1 ), in SBR1, CaP formation was expected to occur during most of the experimental period. The intensity of such a process, however, changed with time. In phase II, when the centrate was supplemented with orthophosphate before being fed to the bioreactor (i.e., within the storage tank), the $\mathrm{Ca} / \mathrm{P}$ molar ratio in the inlet was modified approximately from 2.3 (raw centrate) to 1.3 (expected value after $\mathrm{P}$ supplementation). In these circumstances, the concentration of the soluble ion species involved in the precipitation process could fluctuate significantly because crystallization started just after phosphate addition. On the other hand, that fact might imply the addition of nucleation seeds into the reactor, favoring phosphate precipitation inside. As a rough example for both constituent elements, $\mathrm{P}$ and $\mathrm{Ca}$, by considering the 50 days period between days 125 and 175 (in which differences in the mass flow rates between the inlet and the outlet of the bioreactor were more evident), the outflow rates only averaged 78 and $66 \%$ of the inflow rates, respectively. On adding $\mathrm{Ca}$ to the bioreactor independent of the centrate feeding-in phases III and IV, the concentration of $\mathrm{P}$ in the outlet remained lower steadily over time. The PUE reached significantly higher values, of $71 \pm$ $15 \%$ on average, with a maximum as high as $89 \%$ in some moments (Figure 2). The drop in the efficiency to about $45 \%$ around day 310 was caused by the temporary interruption of Ca supply. On the contrary, in SBR2, no significant phosphate removal from the water line was measured throughout the experimental period, even when $\mathrm{Mg}$ addition was implemented in phase III.

Granular Sludge: Solids Content and Specific Activity in the Bioreactors. The observations made using the stereomicroscope evidenced that the sludge that initially inoculated into the bioreactors was formed by red-colored granules surrounded by brown-colored flocculent biomass. This sludge evolved over time toward a brownish and compact structure forming larger granules (Figure S2). The evolution of the size of the particles constituting the biological sludge was also confirmed quantitatively. Thus, the median particle size in the bioreactors once inoculated (day 0) was measured as $84 \mu \mathrm{m}$ (mode $107 \mu \mathrm{m}$; mean: $121 \mu \mathrm{m}$ ), reaching medians of $380 \mu \mathrm{m}$ in SBR2 and $624 \mu \mathrm{m}$ in SBR1 (modes 431 and $764 \mu \mathrm{m}$; means: 470 and $695 \mu \mathrm{m}$, respectively) after 6 months of running (day 183). By the end of the experimental period (day 440 ), the median size of the granules was measured as $383 \mu \mathrm{m}$ in SBR2 and only as $296 \mu \mathrm{m}$ in SBR1 (modes 416 and 315 $\mu \mathrm{m}$; means: 438 and $328 \mu \mathrm{m}$, respectively), confirming a significant reduction in the case of SBR1. The settling properties of the sludge were assessed throughout the experimental period. The sludge from both bioreactors achieved $\mathrm{SVI}_{30}$ values clearly below $70 \mathrm{~mL} / \mathrm{g}$ TSS and $\mathrm{SVI}_{5} /$ $\mathrm{SVI}_{30}$ ratios lower than 1.8 (and frequently approaching 1.01.2). This is indicative of a very fast settling (sludge settling rates higher than $7 \mathrm{~m} / \mathrm{h}$ could be reached in the first $3 \mathrm{~min}$ ) and gives an excellent indication of the presence of dense granules. ${ }^{28}$ In phases III and IV, the $\mathrm{SVI}_{30}$ measured for SBR1 


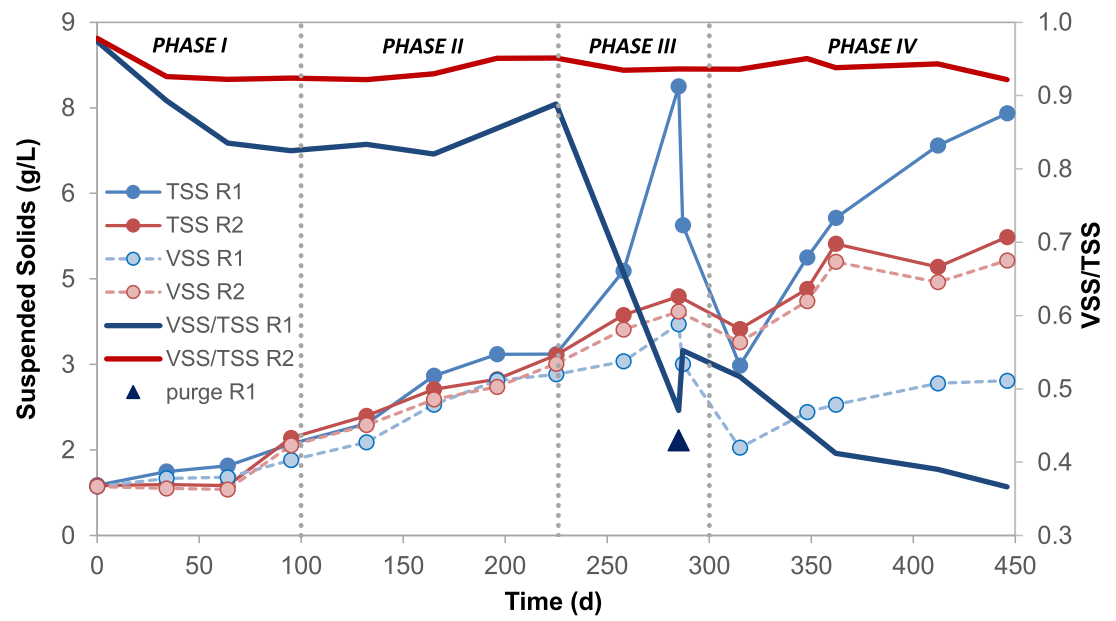

Figure 3. Evolution of the total and volatile suspended solids (TSS and VSS) contents in both bioreactors at the beginning of a new cycle throughout the experimental period.

Table 2. Biological Activity, in Terms of the Specific Nitrogen Conversion Rate (SNCR, $\mathrm{g} \mathrm{N} /(\mathrm{g}$ VSS·days)), Measured in Both PNA SBRs throughout the Experimental Period, According to Their Continuous Performance under Low-Intensity Aeration (On-Site Value), and in Short-Term Batch Incubation Tests Carried Out in Bottles in the Absence of Oxygen to Assess the Specific Anammox Activity (Off-Site Value) ${ }^{a}$

\begin{tabular}{|c|c|c|c|c|}
\hline \multirow{2}{*}{$\frac{\text { bioreactor }}{\downarrow \text { day/value } \rightarrow}$} & \multicolumn{2}{|c|}{ SBR1 } & \multicolumn{2}{|c|}{ SBR2 } \\
\hline & on-site & off-site & on-site & off-site \\
\hline 166 (phase II) & $0.064(0.014)$ & $0.109(0.012)$ & $0.091(0.009)$ & $0.180(0.016)$ \\
\hline 348 (phase IV) & $0.083(0.004)$ & $0.048(0.006)$ & $0.120(0.003)$ & $0.195(0.015)$ \\
\hline 361 (phase IV) & $0.059(0.008)$ & $0.053(0.000)$ & $0.135(0.004)$ & $0.221(0.002)$ \\
\hline
\end{tabular}

${ }^{a}$ Values are means (standard deviation (s.d.) in parentheses).

was systematically lower than for SBR2, likely because of the increase in the mineral content (and density) of the sludge. The formation of HAP in the core of the granules, thus, favored the settling of the sludge within the bioreactor (despite the measured decrease in the size of the granules).

In phases I and II, the supplementation of the centrate fed to SBR1 with a phosphate source resulted in the production of granular sludge with a lower organic content $(82-97 \%$ of the TSS was measured as VSS) than in the case of SBR2 treating raw centrate (92-98\%) (Figure 3). By the end of phase II, although similar VSS contents were measured in both SBRs, i.e., $\sim 2.7 \mathrm{~g} / \mathrm{L}$ by the end of a cycle, different NCRs were determined, i.e., $0.30 \mathrm{~g} \mathrm{NH}_{4}{ }^{+}-\mathrm{N} /$ (L·days) in SBR1 and $0.40 \mathrm{~g}$ $\mathrm{NH}_{4}{ }^{+}-\mathrm{N} /(\mathrm{L} \cdot$ days $)$ in SBR2. By adding Ca to SBR1 in phase III, a sharp decrease in the organic content of the sludge was observed; i.e., from 89 to $47 \%$ in 60 days. This pattern was not observed in SBR2 after adding Mg for the same period, where the organic fraction of the sludge remained above $90 \%$. At this point (day 285; both bioreactors containing $3.4 \mathrm{~g} \mathrm{VSS} / \mathrm{L}$ ), the purge of the largest granules from SBR1 momentarily led to a slight increase in the VSS/TSS ratio of the sludge, but then this ratio continued falling down to a minimum of $37 \%$ by the end of phase IV. After 440 days of running, final VSS contents (end of cycle) in SBR1 and SBR2 were measured as 2.6 and $4.3 \mathrm{~g} / \mathrm{L}$, respectively.

According to the values determined by the end of phase II, the biological activity in both reactors, referred to as the specific NCR (SNCR), was assessed as $0.116 \mathrm{~g} \mathrm{NH}_{4}^{+}-\mathrm{N} /(\mathrm{g}$ VSS.days) for SBR1 and $0.148 \mathrm{~g} \mathrm{NH}_{4}^{+}-\mathrm{N} /$ (g VSS.days) for SBR2 (Table 1). This means a $22 \%$ lower rate in the first bioreactor. These were the highest specific rates reached throughout the experimental period. Smaller values were measured systematically in SBR1, i.e., 10-65\% lower rates in comparison to SBR2 (Figure 1B). By the end of phase IV, the SNCR was $59 \%$ lower in SBR1 than in SBR2, i.e., 0.045 vs $0.110 \mathrm{~g} \mathrm{NH}_{4}^{+}-\mathrm{N} /(\mathrm{g}$ VSS-days). The reduced biological activity of the sludge growing in SBR1 was also confirmed by performing complementary batch incubation tests to assess the specific anammox activity in the short term, as shown in Table 2. For SBR2, the SNCR in such off-site tests was found to be higher than in the bioreactor owing to the strict anoxic conditions imposed. Conversely, this was not always true for SBR1, which might be indicative of some kind of limitation linked to nitrite availability (e.g., related to nitrite mass transfer from the bulk to the mineral-rich inner part of the granule). Concerning $\mathrm{P}$, the maximum PUR measured in SBR1 in phase III, i.e., $12 \mathrm{mg} \mathrm{PO}_{4}-\mathrm{P} /(\mathrm{L} \cdot$ days $)$, was equivalent to a specific value (specific phosphorus uptake rate (SPUR)) of about 3.8 $\mathrm{mg} \mathrm{PO}_{4}-\mathrm{P} /(\mathrm{g}$ VSS $\cdot$ days $)$.

The presence of divalent metal ions in the bulk liquid of the bioreactors, such as $\mathrm{Ca}^{2+}$ and $\mathrm{Mg}^{2+}$, promotes granulation by self-immobilization of the individual microbial cells. It is assumed in the literature that the positive charges of these metal ions can partially neutralize the negative charges on the surface of the microbial cells and extracellular polymeric substances (EPS), which mostly consist of polysaccharides and proteins. Both metal ions can help in enhancing the granulation process, favoring the formation of granules with a more compact and dense structure. ${ }^{29}$ Yet, $\mathrm{Ca}^{2+}$ ions preferably bond with polysaccharides, while $\mathrm{Mg}^{2+}$ ions preferably bond with proteins, which may affect the characteristics of the granular sludge. ${ }^{30}$ In the particular case of the 
Table 3. Comparison of Some Case Studies Concerning Treatment of Real N-Rich Wastewater in Granular Single-Stage Anammox-Based Systems

\begin{tabular}{|c|c|c|c|c|c|c|}
\hline reactor type ${ }^{a}$ & $\begin{array}{l}\text { temperature } \\
\left({ }^{\circ} \mathrm{C}\right)\end{array}$ & wastewater source & $\begin{array}{c}\mathrm{NRR} \\
(\mathrm{g} \mathrm{N} /(\mathrm{L} \cdot \text { days }))\end{array}$ & $\begin{array}{c}\text { SNRR } \\
(\mathrm{g} \mathrm{N} /(\mathrm{g} \text { VSS } \cdot \text { days }))\end{array}$ & $\begin{array}{l}\text { NRE } \\
(\%)\end{array}$ & reference \\
\hline EGSB & 25 & digested pig slurry centrate & 2.71 & 0.35 & 83 & Chini et al. ${ }^{32}$ \\
\hline IL-AR & 30 & $\begin{array}{l}\text { digested pig slurry } \\
\text { (wastewater) }\end{array}$ & 3.90 & 0.35 & 73 & Wang et al. ${ }^{33}$ \\
\hline $\begin{array}{l}\text { SBR (air } \\
\text { pulsing) }\end{array}$ & 21 & urban sidestream centrate & 0.36 & 0.10 & 78 & $\begin{array}{l}\text { Vázquez-Padín } \\
\text { et al. }\end{array}$ \\
\hline SBR & $15-35$ & urban sidestream centrate & $0.30-0.51$ & $0.06-0.11^{b}$ & $81-91$ & Joss et $\mathrm{al}^{35}$ \\
\hline SBR & 28 & urban sidestream centrate & 0.67 & 0.18 & 90 & Jeanningros et al. ${ }^{36}$ \\
\hline SBR & 25 & urban sidestream centrate & $\begin{array}{l}0.27 \text { (SBR1); } 0.35 \\
\quad(\mathrm{SBR} 2)\end{array}$ & $\begin{array}{l}0.10(\mathrm{SBR} 1) ; 0.13 \\
\quad(\mathrm{SBR} 2)\end{array}$ & $\begin{array}{l}75 \text { (SBR1); } 73 \\
\text { (SBR2) }\end{array}$ & this study ${ }^{c}$ \\
\hline
\end{tabular}

${ }^{a}$ Abbreviations: EGSB, expanded granular sludge bed; IL-AR, internal loop airlift reactor; NRE, nitrogen removal efficiency; NRR, nitrogen removal rate; SBR, sequencing batch reactor; SNRR, specific NRR; TSS, total suspended solids; VSS, volatile suspended solids. ${ }^{b}$ VSS/TSS ratio is assumed as $0.75 .{ }^{c}$ Values in terms of conversion rather than removal are (SBR1-SBR2): $0.30-0.40 \mathrm{~g} \mathrm{~N} /(\mathrm{L} \cdot$ days); $0.116-0.148 \mathrm{~g}$ N/(g VSS·days); and $85-83 \%$.

anammox sludge, protein-type EPS play a major role in cell aggregation. ${ }^{31}$ Thus, in phase III, it is hypothesized that the supply of an extra amount of $\mathrm{Mg}^{2+}$ into SBR2 (i.e., the $\mathrm{Ca} / \mathrm{Mg}$ molar ratio added approximately changed from 3.1 to 1.0 ; $\mathrm{min}$ as 0.5 on day 288) could affect ion interactions with EPS and, finally, granule characteristics and process performance.

The coupling of both partial nitritation (eq 1) and anammox (eq 2) processes in one reactor running under low-intensity aeration led to much lower specific N-removal rates (SNRRs) than those expected in anaerobic reactors specifically dedicated to the anammox process, e.g., $1.10 \mathrm{~g} \mathrm{~N} /(\mathrm{g}$ VSS.days), in agreement with the data reported by Strous et al. ${ }^{12}$ Yet, values obtained in this study fall within the range of SNRRs (e.g., 0.06-0.35 $\mathrm{g} \mathrm{N} /$ (g VSS·days)) given in other studies dealing with the treatment of real wastewater in single-stage anammoxbased systems (Table 3)..$^{32-36}$

Besides, the results obtained in this study are in line with those from other similar works combining biological $\mathrm{N}$ removal and mineral crystallization using mechanically stirred bioreactors. As an example, Sperandio et al., ${ }^{37}$ treating synthetic wastewater by nitrification-denitrification in an SBR, showed that phosphate may coprecipitate within the reactor in different forms depending on the $\mathrm{pH}$ (7.5-8.5), including both HAP and MAP. More recently, and concerning single-stage PNA systems, Johansson et al. ${ }^{19}$ successfully treated real urban sidestream centrate in a granular sludge SBR at $25{ }^{\circ} \mathrm{C}$ according to loading rates of $0.31 \mathrm{~g} \mathrm{~N} /(\mathrm{L} \cdot$ days $)$ and $18 \mathrm{mg} \mathrm{P} /(\mathrm{L} \cdot$ days $)$ reaching $66 \% \mathrm{~N}$ removal and HAP recovery without adding chemicals (i.e., wastewater containing $966 \mathrm{mg} \mathrm{NH}_{4}{ }^{+}-\mathrm{N} / \mathrm{L}$ and $57 \mathrm{mg} \mathrm{PO}_{4}-\mathrm{P} / \mathrm{L}$; limited details are available about process performance). By switching to synthetic wastewater and an airlift reactor configuration, Guo and $\mathrm{Li}^{23}$ attained, in a PNA system, removal rates from the water line as high as $1.2 \mathrm{~g} \mathrm{~N} /(\mathrm{L} \cdot$ days $)$ and $70 \mathrm{mg} \mathrm{P} /(\mathrm{L} \cdot$ days $)$ (i.e., wastewater containing $500 \mathrm{mg} \mathrm{NH}{ }_{4}{ }^{+}-\mathrm{N} / \mathrm{L}$ and $20 \mathrm{mg}$ $\left.\mathrm{PO}_{4}-\mathrm{P} / \mathrm{L}\right)$. Finally, much higher process rates were reported for simultaneous $\mathrm{N}$ removal and $\mathrm{P}$ uptake by working with anammox sludge in anaerobic expanded bed reactors fed with synthetic wastewater and running under optimized conditions. In these studies, the NCR (described in terms of N removal) and the PUR (triggering the formation of HAP) from the water line were quantified as high as $16.7 \mathrm{~g} \mathrm{~N} /(\mathrm{L} \cdot$ days $)$ and 1.2 $\mathrm{g} \mathrm{P} /\left(\mathrm{L}\right.$-days) at $25^{\circ} \mathrm{C}^{22}$ or as $44.8 \mathrm{~g} \mathrm{~N} /(\mathrm{L} \cdot$ days $)$ and $0.4 \mathrm{~g} \mathrm{P} /$ (L.days) at $35{ }^{\circ} \mathrm{C} .{ }^{21}$ However, as has been described elsewhere, ${ }^{38-40}$ the accumulation of $\mathrm{Ca}$ inside the granules (mostly as calcium carbonate or $\mathrm{CaP}$ ) implies an enhancement in their mechanical properties, such as a more rigid structure and a higher strength, but as has also been found in this work, at the cost of losing biological activity. ${ }^{23,38,40}$ These operational parameters affecting biomass growth must be particularly considered in the effort to obtain high PURs. In this regard, the NLR and its relationship with the PLR are meaningful, influencing the amount of sludge produced and its composition. To enhance the handling of the purge of the sludge with respect to what has been done in SBR1, the densest granules might be harvested more regularly from the bioreactor, thus preventing the extraction of large amounts of sludge, for instance, using a hydrocyclone. ${ }^{41}$

Composition of the Mineral Phosphate Formed. The mineral fraction of the granular sludge harvested from SBR1 in phase III (Figure 4) was quantified as $53-59 \%$ on a dry weight (DW) basis (Figure 3) when the sample was obtained from the solids' sampling tap (see Figure S1). This sludge contained $10.7 \%$ (DW) P (Table 4), which is a much higher percentage than typical values of $1-2 \%$ in activated sludge or $5-7 \%$ in sludge from biological systems dealing with P removal (EBPR) and enriched in polyphosphate accumulating organisms (PAOs). ${ }^{42}$ Otherwise, the $\mathrm{P}$ content in the sludge from SBR1 was similar to that reported in previous studies targeting concomitant biological $\mathrm{N}$ removal and phosphate precipitation (i.e., $10-16 \%) .{ }^{19,37}$ The mineral fraction of the sludge raised up to $76 \%$ of the DW when only considering those granules that accumulated at the bottom of the bioreactor due to their higher density and which was measured, on a wet weight basis, as $1177 \mathrm{~g} / \mathrm{L}$, which is a similar value to that $(1135 \mathrm{~g} / \mathrm{L})$ reported by Xing et al. ${ }^{40}$ In addition to $\mathrm{P}, \mathrm{Ca}$ was the other main element constituting the mineral fraction of the granules. If referring to the mineral fraction weight (MW), these two elements accounted for 17.9 and $37.9 \%$, respectively. Other constituent elements of the mineral fraction, such as $\mathrm{Mg}$ $(0.34 \%)$ and $\mathrm{K}(0.20 \%)$, were only found in trace amounts. Hence, the $\mathrm{Ca} / \mathrm{P}$ molar ratio of the mineral phosphate formed was calculated as 1.64 , which is very close to the stoichiometric ratio of 1.67 (i.e., 5/3) for HAP. Moreover, the P content in the mineral fraction was similar to that of the phosphate rock, which typically is $13-17.5 \%{ }^{43}$ and to the stoichiometric value for HAP, which is $18.5 \%$. The low amount of $\mathrm{Mg}$ measured excludes the presence of struvite in any major quantities. The analysis of the crystallographic structure using XRD confirmed 

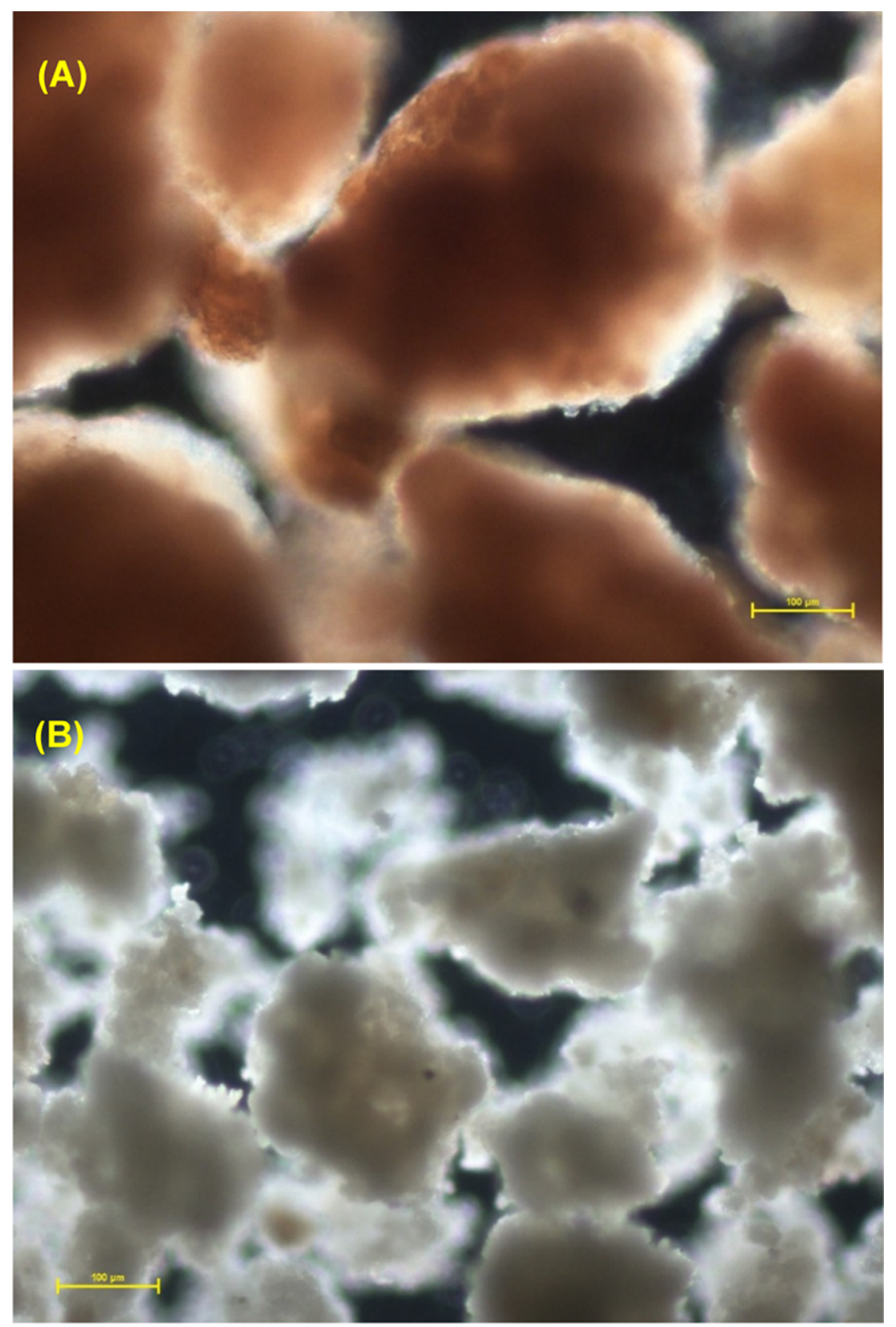

Figure 4. View of the granular sludge growing in SBR1 in phase III (day 285). Fresh sludge (A) and mineral phosphate cores that remained after calcination of the sludge (B).

these results, proving that HAP was the dominant mineral phase (Figure S3).

The presence of metals in the granular sludge formed in SBR1 was quite low, below the proposed EU limits for $\mathrm{P}$ fertilizing products ${ }^{44}$ - the case of $\mathrm{Cr}$ is an exception and could not be assessed since the EU regulation only considers $\mathrm{Cr}$ (VI) and the ICP analysis carried out in this study reports total $\mathrm{Cr}$ without specifying the oxidation state-and also allowing fulfilling the requirements of the $\mathrm{P}$ industry as a raw material. ${ }^{43}$ The contents of $\mathrm{As}, \mathrm{Cd}, \mathrm{Cr}, \mathrm{Cu}, \mathrm{Fe}, \mathrm{Pb}, \mathrm{Hg}, \mathrm{Ni}$, and $\mathrm{Zn}$ in the sludge were measured as $13,0.14,34,15,859,2.6,0.53,14$, and $66 \mathrm{mg} / \mathrm{kg}$ DW, respectively. This chemical composition is in line with the case study previously reported by Johansson et al. ${ }^{19}$ treating similar urban centrate in the same PNA SBR system but without considering the addition of an external $\mathrm{Ca}$ source, although the $\mathrm{Ni}$ and $\mathrm{Pb}$ contents were found to be clearly higher in this study (roughly about an order of magnitude). Contrary to SBR1, no significant mineral formation was observed in SBR2 throughout the experimental period. If we list the contents in the granular sludge of these nine metals in the same order as above, then the measured values were $12,0.12,72,39,1743,22,1.3,81$, and $135 \mathrm{mg} / \mathrm{kg}$ DW, respectively. The higher relative contents of most of the metals in this second case might be justified by the smaller amount of sludge available within the bioreactor acting as a metal accumulator matrix.

The $\mathrm{pH}$ of the bioreactor bulk liquid is a key factor affecting the SI of the phosphate mineral phases. Calculations clearly showed that HAP was the mineral phase with the highest SI values (Figure 5), which means that, thermodynamically, it is the most stable phase. This is in line with the results of the XRD and ICP-OES analyses presented for SBR1 (Table 4). 
Table 4. Elemental Composition of the Granular Sludge, Determined by ICP-OES ${ }^{a, b}$

\begin{tabular}{|c|c|c|c|c|c|c|}
\hline \multirow[b]{2}{*}{ element } & \multicolumn{2}{|c|}{ SBR1 } & \multicolumn{2}{|c|}{ SBR2 } & \multicolumn{2}{|c|}{$\begin{array}{l}\text { Johansson } \\
\text { et al. }\end{array}$} \\
\hline & $\begin{array}{c}\% \\
\text { DW }\end{array}$ & $\begin{array}{c}\% \\
\text { MW }\end{array}$ & $\begin{array}{c}\% \\
\text { DW }\end{array}$ & $\begin{array}{c}\% \\
\text { MW }\end{array}$ & $\begin{array}{c}\% \\
\text { DW }\end{array}$ & $\begin{array}{c}\% \\
\text { MW }\end{array}$ \\
\hline $\mathrm{Ca}$ & 22.5 & 37.9 & 1.4 & 22.1 & 33.5 & 47.2 \\
\hline $\mathrm{P}$ & 10.7 & 17.9 & 1.3 & 20.4 & 15.8 & 22.3 \\
\hline $\mathrm{Mg}$ & 0.20 & 0.34 & 0.25 & 3.88 & 0.24 & 0.34 \\
\hline $\mathrm{K}$ & 0.12 & 0.20 & 0.21 & 3.34 & 0.12 & 0.17 \\
\hline $\begin{array}{l}\text { mineral fraction (\% } \\
\text { DW) }\end{array}$ & \multicolumn{2}{|c|}{$\begin{array}{l}53-59 \text { (76 if } \\
\text { bottom) }\end{array}$} & \multicolumn{2}{|l|}{6} & \multicolumn{2}{|c|}{71 (bottom) } \\
\hline $\mathrm{Ca} / \mathrm{P}$ (molar ratio) & \multicolumn{2}{|l|}{1.64} & \multicolumn{2}{|l|}{0.84} & \multicolumn{2}{|l|}{1.64} \\
\hline
\end{tabular}

${ }^{a}$ Composition is expressed as a percentage of the total dry weight (DW) and as a percentage of the mineral fraction weight (MW). ${ }^{b}$ Samples of granular sludge for chemical analysis were obtained from the bioreactor using the solids' sampling tap (see Figure S1).

Yet, besides thermodynamics, kinetics also determine the formation and growth of the crystals. Thus, although HAP can form directly at low phosphate concentrations without any precursors, its formation is normally preceded by the appearance of other more soluble mineral phases, depending on the $\mathrm{pH}$ value and the composition of the aqueous solution. In this regard, amorphous calcium phosphate (ACP, $\left.\mathrm{Ca}_{3}\left(\mathrm{PO}_{4}\right)_{2} \cdot x \mathrm{H}_{2} \mathrm{O}\right)$ has frequently been suggested as the precursor of HAP in granular sludge systems processing wastewater. ${ }^{24}$ The long retention time of the granules inside the bioreactor will favor the slow transformation of these precursors into HAP, which is the most stable mineral phosphate phase that can be formed, poorly soluble in water. Owing to the fact that ACP (not included in Visual MINTEQ) and TCP have an equivalent $\mathrm{Ca} / \mathrm{P}$ constituent molar ratio (1.5) and similar $K_{\mathrm{sp}}$, both mineral phases are expected to behave similarly in numerical terms at equilibrium (Figure 5). Otherwise, the SI values calculated for MAP were below those calculated for $\mathrm{CaP}$ and lower than zero in the $\mathrm{pH}$ range commonly measured in the bulk of the bioreactors (7.0-7.5), which implies that supersaturation was not reached. This fact points out that the concentration of the constituent ions was too low to cause the precipitation of MAP (even though a raise in the $\mathrm{Mg} / \mathrm{P}$ molar ratio from 0.7 to 2.3 was assumed in SBR2-phase III). Experimentally for SBR2 (Table 4), the potential existence of a local gradient of $\mathrm{pH}$ value within the granule induced by the biological activity was found not to be reason enough to trigger significant HAP or MAP precipitation in its core. At this point, it is worthy to recognize limitations in applying SI calculations to evaluate potential precipitation in complex systems like the one here studied because of the need for appropriate values according to local conditions or the existence of any ion association, complex formation, and hydration in the supersaturated solution.

The formation of HAP in the inner part of the granule (and particularly on the surface of the cell wall-as the site where metabolic fluxes of ions in and out of the cell), rather than in the bulk liquid, has also been reported in other granular PNA systems. ${ }^{19,23}$ In this regard, Guo and $\mathrm{Li}^{23}$ postulated that, initially, simultaneous growth of microbes and formation of HAP crystals triggers the formation of the sludge aggregates. With the increase in size, mass transfer becomes limiting for the microorganisms growing in the inner part of the particle. Finally, these microorganisms will die and decompose, and the space liberated by them will be occupied by new HAP crystals. Eventual local gradients of $\mathrm{pH}$ value (caused by the anammox reaction) and $\mathrm{Ca}^{2+}$ ion concentration (which may be influenced by complexation phenomena with negatively charged EPS and microbial cell surfaces) will affect HAP crystallization. The higher the $\mathrm{pH}$ value, as well as $\mathrm{Ca}$ and phosphate concentrations, the higher the supersaturation reached, benefiting the formation of $\mathrm{CaP}$ mineral phases. The availability of carbonate ions may imply competence for the $\mathrm{Ca}^{2+}$ ions, affecting negatively the removal of phosphate from the bulk liquid.

Microbial Community Composition and Dynamics. The final sequence data set consisted of 6944738 high-quality reads that, on average, were distributed in 257213 reads per

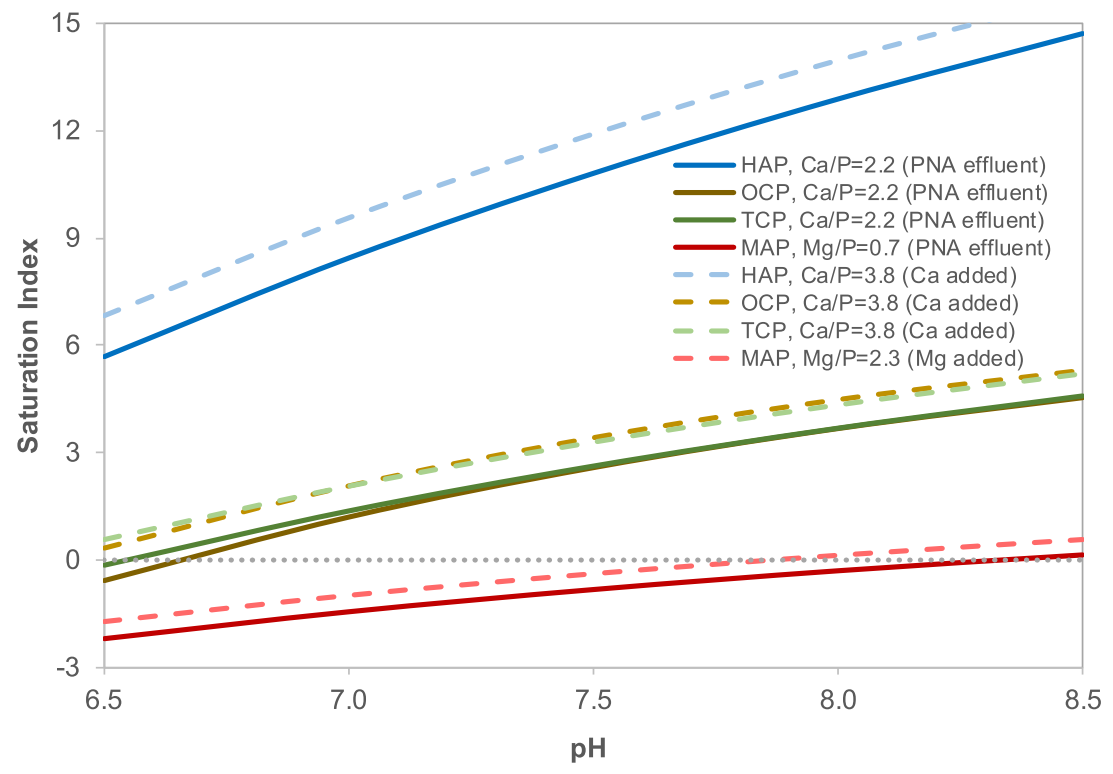

Figure 5. Saturation indexes (SIs) in the bulk of the bioreactor as a function of the $\mathrm{pH}$ value for the mineral phases HAP, OCP, TCP, and MAP. Calculations are based on the average concentrations in the effluent from SBR2 in phase II and, when needed, after adjusting the molar ratios by adding the element referred to in the legend. 

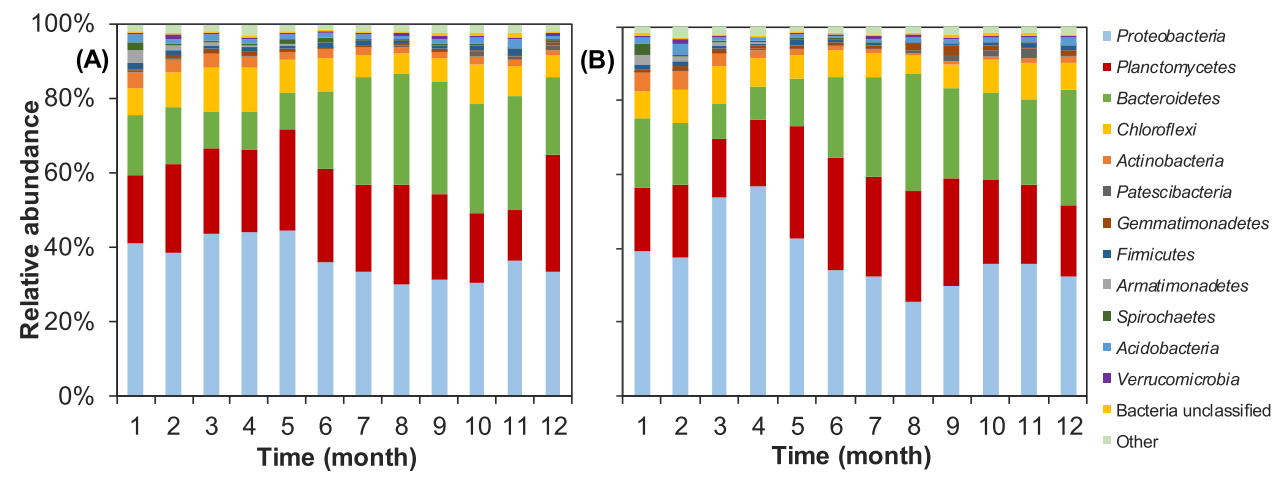

Figure 6. Evolution of the microbial community structure in both SBRs throughout a 12 month experimental period (phase I: months 1-4; phase II: months 5-8; phase III: months 9-10; and phase IV: months 11-12; month 1 is December 2018). The analysis was performed at the phylum level for SBR1 (A) and SBR2 (B). The operational taxonomic units with average relative abundance below $1 \%$ were grouped as "other".

sample $(\min .=130$ 826; $\max .=337$ 792; s.d. $=46028)$. This sampling effort was sufficient to recover most of the prokaryotic diversity, as shown in the rarefaction plot (Figure S4).

Microbial Community Diversity and Richness in the Bioreactors. Table S2 shows the $\alpha$-diversity parameters of the microbial community throughout the bioreactors' operation period. The parameters were calculated after being subsampled in a total of 130826 sequences and at a distance cutoff level of 0.03. The observed number of operational taxonomic units (OTUs, $S_{\text {obs }}$ ) varied between 769 and 1235 in SBR1 and between 587 and 1003 in SBR2, showing a lower richness in the latter. The Simpson diversity index ranged from 0.835 to 0.950 in SBR1 and from 0.897 to 0.948 in SBR2, revealing that community diversity was very similar in both reactors. Bottom sludge showed lower diversity (0.835) and lower richness (836 OTUs) than the side sludge sample-i.e., diversity (0.935) and richness (1029 OTUs)-indicating that the bottom sludge corresponds to a mature microbial community, which will be removed from the bioreactors when purging.

Microbial Community Structure and Dynamics in the Bioreactors. The microbial community structure and dynamics were analyzed through the nonmetric multidimensional scaling (NMDS) method (Figure S5). Main process variable vectors were also added in the NMDS space. The ordination of the samples from both SBRs throughout a 12 month experimental period followed a clear trend according to the phases established. Samples concerning phase I (months 1-4) showed large differences among them owing to the fact that, once the bioreactors started running (using as inoculum a mixture of two different sludges, and processing urban sidestream centrate rather than landfill leachate), the growth of the PNA granules required some months to consolidate. From phase II onward (months 5-12), the divergence in the structure of the microbial community gradually increased with respect to the inoculum (month 1) due to its progressive specialization, according to the raise in the NCRs. Maximal divergence was attained at month 12 in SBR1, whereas similar results were obtained at months 11 and 12 in SBR2.

The evolution of the microbial community structure in both bioreactors at the phylum and genus taxonomic levels is shown in Figures 6 and 7. The main phyla in both bioreactors were Proteobacteria, Planctomycetes, and Bacteroidetes, accounting for 37,23 , and $21 \%$ of the total sequences (on average), respectively (Figure 6). Also commonly present, although in lower percentages, there were Chloroflexi (8\%) and Actino- bacteria (2\%). Other phyla such as Acidobacteria, Armatimonadetes, Firmicutes, Gemmatimonadetes, Patescibacteria, Spirochaetes, and Verrucomicrobia were detected regularly but averaging relative abundances $<1 \%$. Planctomycetes, which harbors the AnAOB representatives, reached maximum relative abundances in phase II, when maximum SNCRs were also described (Figure 1B). Bacteroidetes decreased in phase I, from 16 to $10 \%$ in SBR1 and from 19 to $9 \%$ in SBR2, according to the operational conditions imposed in both bioreactors during the startup. Nevertheless, the relative abundances in the following months rose up to 31 and $32 \%$ in SBR1 and SBR2, respectively. These percentages were more fluctuant in SBR2. Although Chloroflexi was not dominant, it was consistently detected in both SBR reactors (maximum relative abundances were measured by the end of phase I, i.e., $12 \%$ in SBR1 and $10 \%$ in SBR2). Indeed, this phylum is considered to be involved in the stabilization of the granules, as will be discussed further on.

Proteobacteria is one of the main phyla commonly found in $\mathrm{N}$-removal bioreactors, which harbors many nitrifying and denitrifying representatives, and therefore, it is crucial in $\mathrm{N}$ removal processes. ${ }^{45-47}$ The phylum Planctomycetes plays a decisive role in PNA SBRs since it contains all known anammox genera. ${ }^{48}$ Other phyla such as Bacteroidetes and Chloroflexi harbor members potentially capable of facilitating a nitrite loop with AnAOB, or support denitrification, thus contributing to overall $\mathrm{N}$ removal in the bioreactors. ${ }^{49,50}$ Moreover, the function of these bacterial phyla in the PNA SBRs is far from being limited to bioconversions within the Ncycle. ${ }^{51}$ Thus, for instance, some representatives of both, Bacteroidetes and Chloroflexi, are functionally closely related since both groups include heterotrophic bacteria, which may consume soluble microbial products and EPS, i.e., proteins and polysaccharides, released by the existing microorganisms. $^{49,52,53}$ Moreover, Chloroflexi are filamentous bacteria, which may contribute to the initial formation and further stabilization of the granules ${ }^{53}$ and benefit from decaying bacterial cell materials according to their heterotrophic metabolism, avoiding the accumulation of bacterial debris and other organic compounds. ${ }^{52}$

At the genus level, from a total of 1023 taxons retrieved in samples collected from both bioreactors, only 80 ( $8 \%$ of the total) showed relative abundances $\geq 1 \%$ (i.e., above $0.55 \%$ ) in at least one sample. Overall, the dominant genera in both SBRs, showing average percentages above $5 \%$, were Candidatus Kuenenia [Planctomycetes] (21\%), Arenimonas [Gammapro- 


\begin{tabular}{|c|c|c|c|c|c|c|c|c|c|c|c|c|}
\hline$\downarrow$ OTU ID / Time (month) $\rightarrow$ & 1 & 2 & 3 & 4 & 5 & 6 & 7 & 8 & 9 & 10 & 11 & 12 \\
\hline \multicolumn{13}{|l|}{ Proteobacteria } \\
\hline \multicolumn{13}{|l|}{ c_Alphaproteobacteria } \\
\hline Brevundimonas & $0 \%$ & $0 \%$ & $0 \%$ & $0 \%$ & $0 \%$ & $1 \%$ & $0 \%$ & $1 \%$ & $1 \%$ & $1 \%$ & $2 \%$ & $1 \%$ \\
\hline Rhizobiaceae unclassified & $2 \%$ & $1 \%$ & $0 \%$ & $1 \%$ & $1 \%$ & $1 \%$ & $0 \%$ & $0 \%$ & $0 \%$ & $0 \%$ & $0 \%$ & $0 \%$ \\
\hline Hyphomicrobiaceae unclassified & $1 \%$ & $1 \%$ & $1 \%$ & $1 \%$ & $0 \%$ & $0 \%$ & $0 \%$ & $0 \%$ & $0 \%$ & $0 \%$ & $0 \%$ & $0 \%$ \\
\hline Rhodobacteraceae unclassified & $1 \%$ & $0 \%$ & $0 \%$ & $0 \%$ & $0 \%$ & $0 \%$ & $1 \%$ & $1 \%$ & $1 \%$ & $1 \%$ & $1 \%$ & $1 \%$ \\
\hline Unclassified & $0 \%$ & $0 \%$ & $0 \%$ & $0 \%$ & $0 \%$ & $0 \%$ & $0 \%$ & $0 \%$ & $0 \%$ & $0 \%$ & $1 \%$ & $0 \%$ \\
\hline \multicolumn{13}{|l|}{ c_Betaproteobacteria } \\
\hline Nitrosomonas & $4 \%$ & $3 \%$ & $3 \%$ & $5 \%$ & $7 \%$ & $5 \%$ & $3 \%$ & $5 \%$ & $5 \%$ & $4 \%$ & $7 \%$ & $11 \%$ \\
\hline Burkholderiaceae unclassified & $7 \%$ & $1 \%$ & $1 \%$ & $1 \%$ & $1 \%$ & $0 \%$ & $0 \%$ & $0 \%$ & $0 \%$ & $1 \%$ & $1 \%$ & $1 \%$ \\
\hline Ellin6067 & $0 \%$ & $0 \%$ & $0 \%$ & $0 \%$ & $0 \%$ & $0 \%$ & $0 \%$ & $0 \%$ & $0 \%$ & $0 \%$ & $1 \%$ & $0 \%$ \\
\hline Limnobacter & $2 \%$ & $1 \%$ & $1 \%$ & $1 \%$ & $2 \%$ & $1 \%$ & $2 \%$ & $2 \%$ & $3 \%$ & $4 \%$ & $4 \%$ & $1 \%$ \\
\hline Comamonas & $1 \%$ & $2 \%$ & $2 \%$ & $2 \%$ & $1 \%$ & $1 \%$ & $1 \%$ & $1 \%$ & $1 \%$ & $1 \%$ & $1 \%$ & $0 \%$ \\
\hline Pusillimonas & $2 \%$ & $0 \%$ & $0 \%$ & $0 \%$ & $0 \%$ & $0 \%$ & $0 \%$ & $0 \%$ & $0 \%$ & $0 \%$ & $0 \%$ & $0 \%$ \\
\hline Thiobacillus & $0 \%$ & $0 \%$ & $0 \%$ & $0 \%$ & $0 \%$ & $0 \%$ & $2 \%$ & $2 \%$ & $1 \%$ & $0 \%$ & $0 \%$ & $0 \%$ \\
\hline Denitratisoma & $0 \%$ & $0 \%$ & $0 \%$ & $0 \%$ & $0 \%$ & $0 \%$ & $0 \%$ & $0 \%$ & $0 \%$ & $0 \%$ & $0 \%$ & $5 \%$ \\
\hline \multicolumn{13}{|l|}{ c_Gammaproteobacteria } \\
\hline Arenimonas & $4 \%$ & $14 \%$ & $20 \%$ & $18 \%$ & $15 \%$ & $11 \%$ & $7 \%$ & $4 \%$ & $3 \%$ & $3 \%$ & $3 \%$ & $2 \%$ \\
\hline Thermomonas & $0 \%$ & $0 \%$ & $0 \%$ & $0 \%$ & $2 \%$ & $1 \%$ & $0 \%$ & $0 \%$ & $0 \%$ & $0 \%$ & $0 \%$ & $0 \%$ \\
\hline Dokdonella & $1 \%$ & $1 \%$ & $2 \%$ & $2 \%$ & $2 \%$ & $1 \%$ & $1 \%$ & $1 \%$ & $1 \%$ & $1 \%$ & $1 \%$ & $0 \%$ \\
\hline Luteibacter & $5 \%$ & $2 \%$ & $1 \%$ & $1 \%$ & $1 \%$ & $0 \%$ & $0 \%$ & $0 \%$ & $0 \%$ & $0 \%$ & $0 \%$ & $0 \%$ \\
\hline Sedimenticola & $0 \%$ & $2 \%$ & $1 \%$ & $1 \%$ & $1 \%$ & $1 \%$ & $0 \%$ & $0 \%$ & $0 \%$ & $0 \%$ & $0 \%$ & $0 \%$ \\
\hline PLTA13 & $0 \%$ & $0 \%$ & $0 \%$ & $1 \%$ & $1 \%$ & $3 \%$ & $4 \%$ & $5 \%$ & $4 \%$ & $5 \%$ & $5 \%$ & $3 \%$ \\
\hline Steroidobacter & $2 \%$ & $1 \%$ & $2 \%$ & $1 \%$ & $2 \%$ & $2 \%$ & $2 \%$ & $1 \%$ & $1 \%$ & $1 \%$ & $1 \%$ & $0 \%$ \\
\hline 1013-28-CG33 & $0 \%$ & $0 \%$ & $0 \%$ & $0 \%$ & $0 \%$ & $0 \%$ & $0 \%$ & $0 \%$ & $1 \%$ & $1 \%$ & $1 \%$ & $1 \%$ \\
\hline Unclassified & $1 \%$ & $1 \%$ & $1 \%$ & $1 \%$ & $1 \%$ & $1 \%$ & $1 \%$ & $1 \%$ & $1 \%$ & $0 \%$ & $0 \%$ & $1 \%$ \\
\hline \multicolumn{13}{|l|}{ c_Deltaproteobacteria } \\
\hline Blrii41 & $0 \%$ & $1 \%$ & $1 \%$ & $1 \%$ & $0 \%$ & $1 \%$ & $2 \%$ & $1 \%$ & $1 \%$ & $1 \%$ & $1 \%$ & $1 \%$ \\
\hline Pajaroellobacter & $0 \%$ & $0 \%$ & $0 \%$ & $0 \%$ & $0 \%$ & $1 \%$ & $0 \%$ & $1 \%$ & $1 \%$ & $1 \%$ & $0 \%$ & $0 \%$ \\
\hline $0319-6 \mathrm{G} 20$ & $0 \%$ & $0 \%$ & $0 \%$ & $0 \%$ & $0 \%$ & $0 \%$ & $0 \%$ & $0 \%$ & $0 \%$ & $0 \%$ & $0 \%$ & $0 \%$ \\
\hline Syntrophaceae unclassified & $0 \%$ & $0 \%$ & $0 \%$ & $0 \%$ & $0 \%$ & $0 \%$ & $1 \%$ & $0 \%$ & $0 \%$ & $0 \%$ & $0 \%$ & $0 \%$ \\
\hline
\end{tabular}

\begin{tabular}{llllllllllll}
\hline 1 & 2 & 3 & 4 & 5 & 6 & 7 & 8 & 9 & 10 & 11 & 12 \\
\hline
\end{tabular}

$\begin{array}{llllllllllll}0 \% & 0 \% & 0 \% & 0 \% & 1 \% & 0 \% & 3 \% & 1 \% & 2 \% & 1 \% & 1 \% & 1 \%\end{array}$ $\begin{array}{llllllllllll}2 \% & 1 \% & 1 \% & 1 \% & 1 \% & 1 \% & 0 \% & 0 \% & 0 \% & 0 \% & 1 \% & 0 \%\end{array}$ $\begin{array}{llllllllllll}1 \% & 2 \% & 1 \% & 0 \% & 0 \% & 0 \% & 0 \% & 0 \% & 0 \% & 0 \% & 0 \% & 0 \%\end{array}$ \begin{tabular}{llllllllllll}
$1 \%$ & $0 \%$ & $0 \%$ & $0 \%$ & $0 \%$ & $1 \%$ & $1 \%$ & $1 \%$ & $1 \%$ & $1 \%$ & $1 \%$ & $1 \%$ \\
\hline & $0 \%$ & $0 \%$ & $0 \%$ & $0 \%$ & $0 \%$ & $0 \%$ & $0 \%$ & $0 \%$ & $0 \%$ & $0 \%$ & $0 \%$
\end{tabular} \begin{tabular}{lllllllllllll|}
$4 \%$ & $5 \%$ & $4 \%$ & $7 \%$ & $9 \%$ & $8 \%$ & $3 \%$ & $3 \%$ & $6 \%$ & $11 \%$ & $9 \%$ & $7 \%$ \\
\hline
\end{tabular} $\begin{array}{llllllllllll}6 \% & 1 \% & 1 \% & 1 \% & 0 \% & 0 \% & 0 \% & 1 \% & 1 \% & 1 \% & 1 \% & 1 \%\end{array}$ $\begin{array}{llllllllllll}0 \% & 0 \% & 0 \% & 0 \% & 0 \% & 0 \% & 0 \% & 0 \% & 0 \% & 0 \% & 0 \% & 0 \%\end{array}$

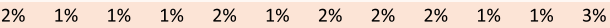

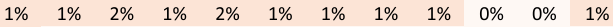
$\begin{array}{llllllllllll}3 \% & 0 \% & 0 \% & 0 \% & 0 \% & 0 \% & 0 \% & 0 \% & 0 \% & 0 \% & 0 \% & 0 \%\end{array}$ $\begin{array}{llllllllllll}0 \% & 0 \% & 0 \% & 0 \% & 1 \% & 1 \% & 1 \% & 1 \% & 1 \% & 0 \% & 0 \% & 0 \%\end{array}$ $\begin{array}{llllllllllll}0 \% & 0 \% & 0 \% & 0 \% & 0 \% & 0 \% & 1 \% & 1 \% & 3 \% & 4 \% & 5 \% & 1 \%\end{array}$

$\begin{array}{llllllllllll}5 \% & 13 \% & 25 \% & 25 \% & 11 \% & 6 \% & 4 \% & 2 \% & 2 \% & 1 \% & 3 \% & 2 \%\end{array}$ $\begin{array}{llllllllllll}0 \% & 0 \% & 0 \% & 5 \% & 1 \% & 0 \% & 0 \% & 0 \% & 0 \% & 0 \% & 0 \% & 0 \%\end{array}$ $\begin{array}{llllllllllll}0 \% & 1 \% & 3 \% & 2 \% & 2 \% & 1 \% & 1 \% & 0 \% & 0 \% & 0 \% & 0 \% & 1 \%\end{array}$ $\begin{array}{llllllllllll}5 \% & 2 \% & 2 \% & 1 \% & 0 \% & 0 \% & 0 \% & 0 \% & 0 \% & 0 \% & 0 \% & 0 \%\end{array}$ $\begin{array}{llllllllllll}1 \% & 2 \% & 1 \% & 1 \% & 0 \% & 0 \% & 0 \% & 0 \% & 0 \% & 0 \% & 0 \% & 0 \%\end{array}$ $\begin{array}{llllllllllll}0 \% & 0 \% & 0 \% & 1 \% & 2 \% & 3 \% & 4 \% & 5 \% & 4 \% & 4 \% & 5 \% & 5 \%\end{array}$ $\begin{array}{llllllllllll}2 \% & 1 \% & 2 \% & 2 \% & 2 \% & 2 \% & 1 \% & 1 \% & 1 \% & 0 \% & 0 \% & 1 \%\end{array}$ $\begin{array}{llllllllllll}0 \% & 0 \% & 0 \% & 0 \% & 0 \% & 0 \% & 0 \% & 0 \% & 0 \% & 0 \% & 0 \% & 1 \%\end{array}$

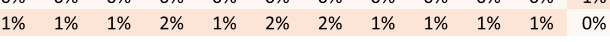

$\begin{array}{llllllllllll}0 \% & 2 \% & 2 \% & 1 \% & 1 \% & 2 \% & 2 \% & 1 \% & 1 \% & 2 \% & 2 \% & 2 \%\end{array}$ $\begin{array}{llllllllllll}0 \% & 0 \% & 0 \% & 0 \% & 0 \% & 0 \% & 1 \% & 0 \% & 1 \% & 0 \% & 0 \% & 0 \%\end{array}$ $\begin{array}{llllllllllll}1 \% & 0 \% & 0 \% & 0 \% & 0 \% & 0 \% & 0 \% & 0 \% & 0 \% & 0 \% & 0 \% & 0 \%\end{array}$ $\begin{array}{llllllllllll}0 \% & 0 \% & 0 \% & 0 \% & 0 \% & 0 \% & 0 \% & 0 \% & 0 \% & 0 \% & 0 \% & 0 \%\end{array}$

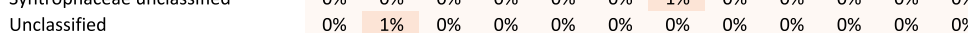
Planctomycetes

f_Brocadiaceae

$f_{-}$Brocadiaceo

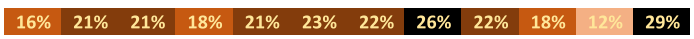

\begin{tabular}{llllllllllll}
$0 \%$ & $1 \%$ & $0 \%$ & $0 \%$ & $0 \%$ & $0 \%$ & $0 \%$ & $0 \%$ & $0 \%$ & $0 \%$ & $0 \%$ & $0 \%$ \\
\hline
\end{tabular}

Other

Pirellula

Planctomicrobium

$\begin{array}{llllllllllll}1 \% & 0 \% & 0 \% & 0 \% & 0 \% & 0 \% & 0 \% & 0 \% & 0 \% & 0 \% & 0 \% & 0 \%\end{array}$

$\begin{array}{lllllllllllll}0 \% & 0 \% & 0 \% & 0 \% & 1 \% & 0 \% & 0 \% & 0 \% & 0 \% & 0 \% & 0 \% & 0 \%\end{array}$

S-70 $\begin{array}{llllllllllll}0 \% & 0 \% & 0 \% & 0 \% & 0 \% & 0 \% & 0 \% & 0 \% & 0 \% & 0 \% & 0 \% & 0 \%\end{array}$

Bacteroidetes

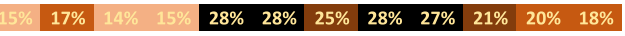

c_lgnavibacteriales

PHOS-HE36

Ignavibacterium

IheB3-7

c_Chitinophagales

Unclassified 1

Membranicola

OLB8

Phaeodactylibacter

37-13

Ferruginibacter

Chitinophagaceae unclassified

Unclassified 2

Other

Lentimicrobiaceae unclassified

AKYH767

NS11-12 marine group

env.OPS 17

NS9 marine group

Moheibacter

DMER64

OPB56

SJA-28

Balneola

Unclassified

Chloroflexi

SBR1031

A4b

OLB14
JG30-KF-CM66

Unclassified 1

Unclassified 2

Actinobacteria

$67-14$

IMCC26207

Actinomarinales unclassified

Microbacteriaceae unclassified

\begin{tabular}{lllllllllllll|l}
$0 \%$ & $0 \%$ & $0 \%$ & $1 \%$ & $1 \%$ & $5 \%$ & $7 \%$ & $10 \%$ & $11 \%$ & $16 \%$ & $15 \%$ & $10 \%$
\end{tabular}

$\begin{array}{llllllllllll}0 \% & 0 \% & 0 \% & 0 \% & 0 \% & 2 \% & 3 \% & 0 \% & 0 \% & 0 \% & 0 \% & 0 \%\end{array}$

$\begin{array}{llllllllllll}0 \% & 1 \% & 1 \% & 0 \% & 0 \% & 0 \% & 0 \% & 0 \% & 0 \% & 0 \% & 0 \% & 0 \%\end{array}$

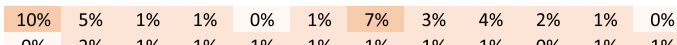

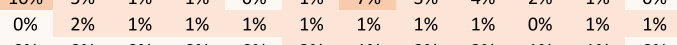
$\begin{array}{llllllllllll}0 \% & 0 \% & 0 \% & 0 \% & 0 \% & 3 \% & 1 \% & 3 \% & 2 \% & 1 \% & 1 \% & 0 \%\end{array}$ $\begin{array}{llllllllllll}0 \% & 0 \% & 0 \% & 0 \% & 1 \% & 1 \% & 1 \% & 1 \% & 0 \% & 0 \% & 0 \% & 0 \% \\ 0 \% & 1 \% & 0 \% & 0 \% & 0 \% & 0 \% & 0 \% & 0 \% & 0 \% & 0 \% & 0 \% & 0 \%\end{array}$ $\begin{array}{llllllllllll}0 \% & 0 \% & 0 \% & 0 \% & 0 \% & 0 \% & 0 \% & 0 \% & 0 \% & 0 \% & 0 \% & 3 \%\end{array}$ $\begin{array}{lllllllllllll}0 \% & 0 \% & 0 \% & 0 \% & 0 \% & 2 \% & 5 \% & 7 \% & 3 \% & 3 \% & 2 \% & 1 \%\end{array}$

$\begin{array}{llllllllllll}0 \% & 0 \% & 0 \% & 0 \% & 0 \% & 1 \% & 0 \% & 0 \% & 2 \% & 1 \% & 0 \% & 0 \%\end{array}$

$\begin{array}{llllllllllll}1 \% & 2 \% & 2 \% & 1 \% & 1 \% & 1 \% & 1 \% & 1 \% & 1 \% & 1 \% & 1 \% & 0 \%\end{array}$

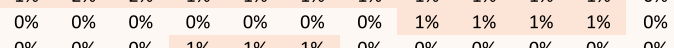
$\begin{array}{llllllllllll}0 \% & 0 \% & 0 \% & 1 \% & 1 \% & 1 \% & 0 \% & 0 \% & 0 \% & 0 \% & 0 \% & 0 \%\end{array}$ \begin{tabular}{llllllllllll|}
\hline$\%$ & $0 \%$ & $0 \%$ & $0 \%$ & $0 \%$ & $0 \%$ & $0 \%$ & $0 \%$ & $0 \%$ & $0 \%$ & $0 \%$ & $1 \%$ \\
\hline
\end{tabular} \begin{tabular}{lllllllllllll}
\hline$\%$ & $0 \%$ & $0 \%$ & $0 \%$ & $0 \%$ & $0 \%$ & $0 \%$ & $0 \%$ & $1 \%$ & $0 \%$ & $1 \%$ & $0 \%$ \\
\hline
\end{tabular} $\begin{array}{llllllllllll}0 \% & 1 \% & 1 \% & 0 \% & 0 \% & 0 \% & 0 \% & 0 \% & 0 \% & 0 \% & 0 \% & 0 \%\end{array}$ $\begin{array}{llllllllllll}0 \% & 0 \% & 0 \% & 1 \% & 1 \% & 1 \% & 0 \% & 0 \% & 0 \% & 0 \% & 0 \% & 0 \%\end{array}$ \begin{tabular}{llllllllllll}
$0 \%$ & $0 \%$ & $0 \%$ & $0 \%$ & $0 \%$ & $0 \%$ & $0 \%$ & $1 \%$ & $0 \%$ & $1 \%$ & $1 \%$ & $0 \%$ \\
\hline
\end{tabular} $\begin{array}{llllllllllll}0 \% & 0 \% & 0 \% & 0 \% & 0 \% & 0 \% & 0 \% & 0 \% & 1 \% & 1 \% & 1 \% & 1 \%\end{array}$ $\begin{array}{llllllllllll}1 \% & 0 \% & 0 \% & 0 \% & 0 \% & 0 \% & 0 \% & 0 \% & 0 \% & 0 \% & 0 \% & 0 \%\end{array}$ $\begin{array}{llllllllllll}1 \% & 0 \% & 0 \% & 0 \% & 0 \% & 0 \% & 0 \% & 0 \% & 0 \% & 0 \% & 0 \% & 0 \%\end{array}$ $\begin{array}{llllllllllll}0 \% & 0 \% & 0 \% & 0 \% & 0 \% & 0 \% & 0 \% & 1 \% & 1 \% & 1 \% & 1 \% & 1 \%\end{array}$

\begin{tabular}{llll|llllllll}
$3 \%$ & $5 \%$ & $7 \%$ & $6 \%$ & $5 \%$ & $5 \%$ & $3 \%$ & $2 \%$ & $2 \%$ & $4 \%$ & $3 \%$ & $2 \%$
\end{tabular} $\begin{array}{llllllllllll}0 \% & 0 \% & 0 \% & 0 \% & 0 \% & 1 \% & 1 \% & 1 \% & 1 \% & 3 \% & 2 \% & 1 \%\end{array}$ $\begin{array}{llllllllllll}0 \% & 0 \% & 0 \% & 0 \% & 0 \% & 0 \% & 1 \% & 1 \% & 1 \% & 1 \% & 1 \% & 1 \%\end{array}$

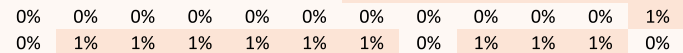
$\begin{array}{llllllllllll}1 \% & 2 \% & 1 \% & 2 \% & 1 \% & 1 \% & 1 \% & 1 \% & 0 \% & 1 \% & 0 \% & 1 \%\end{array}$

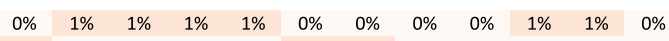
\begin{tabular}{lllllllllllll}
$1 \%$ & $0 \%$ & $0 \%$ & $0 \%$ & $0 \%$ & $1 \%$ & $1 \%$ & $0 \%$ & $0 \%$ & $0 \%$ & $0 \%$ & $0 \%$ \\
\hline 0 & $0 \%$ & $0 \%$ & $0 \%$ & $0 \%$ & $0 \%$ & $0 \%$ & $0 \%$ & $0 \%$ & $0 \%$ & $0 \%$ & $0 \%$
\end{tabular}

$\begin{array}{llllllllllll}2 \% & 1 \% & 1 \% & 0 \% & 0 \% & 0 \% & 0 \% & 0 \% & 0 \% & 0 \% & 0 \% & 0 \%\end{array}$ $\begin{array}{llllllllllll}0 \% & 0 \% & 0 \% & 0 \% & 1 \% & 1 \% & 0 \% & 0 \% & 0 \% & 0 \% & 0 \% & 0 \%\end{array}$ $\begin{array}{llllllllllll}1 \% & 0 \% & 0 \% & 0 \% & 0 \% & 0 \% & 0 \% & 0 \% & 0 \% & 0 \% & 0 \% & 0 \%\end{array}$

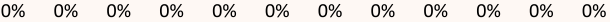
$\begin{array}{llllllllllll}0 \% & 0 \% & 0 \% & 1 \% & 0 \% & 0 \% & 0 \% & 0 \% & 0 \% & 0 \% & 0 \% & 0 \%\end{array}$ \begin{tabular}{llllllllllll}
$0 \%$ & $0 \%$ & $0 \%$ & $0 \%$ & $0 \%$ & $1 \%$ & $0 \%$ & $0 \%$ & $0 \%$ & $0 \%$ & $0 \%$ & $0 \%$ \\
\hline
\end{tabular}

\begin{tabular}{lllllllllll|l}
$0 \%$ & $0 \%$ & $0 \%$ & $1 \%$ & $3 \%$ & $5 \%$ & $5 \%$ & $10 \%$ & $10 \%$ & $11 \%$ & $13 \%$ & $20 \%$ \\
\hline
\end{tabular} $\begin{array}{lllllllllllll}0 \% & 0 \% & 0 \% & 0 \% & 0 \% & 2 \% & 1 \% & 1 \% & 0 \% & 0 \% & 0 \% & 0 \%\end{array}$ $\begin{array}{llllllllllll}0 \% & 1 \% & 0 \% & 0 \% & 0 \% & 0 \% & 0 \% & 0 \% & 0 \% & 0 \% & 0 \% & 0 \%\end{array}$

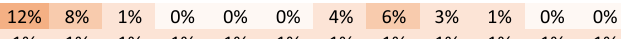

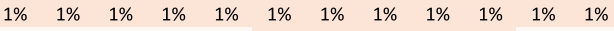
$\begin{array}{llllllllllll}0 \% & 0 \% & 0 \% & 0 \% & 0 \% & 3 \% & 4 \% & 4 \% & 1 \% & 1 \% & 0 \% & 0 \%\end{array}$ $\begin{array}{llllllllllll}0 \% & 0 \% & 0 \% & 0 \% & 1 \% & 1 \% & 1 \% & 1 \% & 1 \% & 0 \% & 1 \% & 0 \%\end{array}$ $\begin{array}{llllllllllll}0 \% & 0 \% & 0 \% & 0 \% & 0 \% & 0 \% & 0 \% & 0 \% & 0 \% & 0 \% & 0 \% & 0 \%\end{array}$ $\begin{array}{llllllllllll}0 \% & 0 \% & 0 \% & 0 \% & 0 \% & 0 \% & 0 \% & 1 \% & 1 \% & 2 \% & 2 \% & 0 \%\end{array}$ $\begin{array}{lllllllllllll}0 \% & 0 \% & 0 \% & 0 \% & 1 \% & 3 \% & 1 \% & 1 \% & 2 \% & 1 \% & 1 \% & 3 \%\end{array}$ $\begin{array}{llllllllllll}0 \% & 0 \% & 0 \% & 0 \% & 0 \% & 0 \% & 1 \% & 0 \% & 0 \% & 0 \% & 0 \% & 0 \%\end{array}$

$\begin{array}{llllllllllll}1 \% & 1 \% & 2 \% & 1 \% & 1 \% & 1 \% & 1 \% & 1 \% & 1 \% & 0 \% & 0 \% & 0 \%\end{array}$

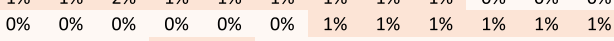
$\begin{array}{llllllllllll}0 \% & 0 \% & 0 \% & 1 \% & 1 \% & 0 \% & 0 \% & 0 \% & 0 \% & 0 \% & 0 \% & 0 \%\end{array}$ $\begin{array}{llllllllllll}0 \% & 0 \% & 0 \% & 0 \% & 0 \% & 0 \% & 2 \% & 0 \% & 1 \% & 1 \% & 0 \% & 0 \%\end{array}$ $\begin{array}{llllllllllll}0 \% & 0 \% & 0 \% & 1 \% & 0 \% & 0 \% & 1 \% & 0 \% & 0 \% & 0 \% & 0 \% & 0 \%\end{array}$ $\begin{array}{llllllllllll}0 \% & 1 \% & 1 \% & 0 \% & 0 \% & 0 \% & 0 \% & 0 \% & 0 \% & 0 \% & 0 \% & 0 \%\end{array}$ $\begin{array}{llllllllllll}0 \% & 0 \% & 0 \% & 1 \% & 1 \% & 0 \% & 0 \% & 0 \% & 0 \% & 0 \% & 0 \% & 0 \%\end{array}$ $\begin{array}{lllllllllllll}0 \% & 0 \% & 0 \% & 0 \% & 1 \% & 2 \% & 2 \% & 2 \% & 0 \% & 0 \% & 1 \% & 1 \%\end{array}$ $\begin{array}{llllllllllll}0 \% & 0 \% & 0 \% & 0 \% & 0 \% & 0 \% & 0 \% & 1 \% & 0 \% & 1 \% & 1 \% & 1 \%\end{array}$ $\begin{array}{llllllllllll}1 \% & 1 \% & 0 \% & 0 \% & 0 \% & 0 \% & 0 \% & 0 \% & 0 \% & 0 \% & 0 \% & 0 \%\end{array}$ $\begin{array}{llllllllllll}1 \% & 0 \% & 0 \% & 0 \% & 0 \% & 0 \% & 0 \% & 0 \% & 0 \% & 0 \% & 0 \% & 0 \%\end{array}$ \begin{tabular}{llllllllllll}
$0 \%$ & $0 \%$ & $0 \%$ & $0 \%$ & $0 \%$ & $0 \%$ & $0 \%$ & $1 \%$ & $0 \%$ & $1 \%$ & $1 \%$ & $1 \%$ \\
\hline
\end{tabular}

$\begin{array}{llllllllllll}3 \% & 5 \% & 5 \% & 4 \% & 3 \% & 4 \% & 3 \% & 2 \% & 2 \% & 4 \% & 4 \% & 2 \%\end{array}$ $\begin{array}{llllllllllll}0 \% & 0 \% & 0 \% & 0 \% & 0 \% & 0 \% & 1 \% & 1 \% & 1 \% & 1 \% & 2 \% & 2 \%\end{array}$ $\begin{array}{lllllllllllll}0 \% & 0 \% & 0 \% & 0 \% & 1 \% & 0 \% & 1 \% & 0 \% & 0 \% & 0 \% & 1 \% & 1 \%\end{array}$ $\begin{array}{llllllllllll}0 \% & 0 \% & 0 \% & 0 \% & 0 \% & 0 \% & 0 \% & 0 \% & 0 \% & 0 \% & 0 \% & 0 \%\end{array}$ $\begin{array}{llllllllllll}0 \% & 1 \% & 1 \% & 1 \% & 1 \% & 0 \% & 0 \% & 0 \% & 0 \% & 1 \% & 1 \% & 1 \%\end{array}$ \begin{tabular}{llllllllllll}
$1 \%$ & $1 \%$ & $1 \%$ & $1 \%$ & $1 \%$ & $2 \%$ & $1 \%$ & $0 \%$ & $1 \%$ & $2 \%$ & $1 \%$ & $0 \%$ \\
\hline
\end{tabular} \begin{tabular}{|l|l|l|l|l|l|l|l|l|l|l|l|}
\hline $0 \%$ & $1 \%$ & $1 \%$ & $0 \%$ & $1 \%$ & $0 \%$ & $0 \%$ & $0 \%$ & $0 \%$ & $0 \%$ & $0 \%$ & $1 \%$ \\
\hline
\end{tabular} $\begin{array}{llllllllllll}1 \% & 0 \% & 0 \% & 0 \% & 0 \% & 0 \% & 0 \% & 0 \% & 0 \% & 0 \% & 0 \% & 0 \%\end{array}$

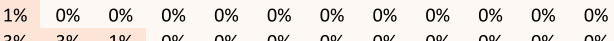

$\begin{array}{llllllllllll}3 \% & 3 \% & 1 \% & 0 \% & 0 \% & 0 \% & 0 \% & 0 \% & 0 \% & 0 \% & 0 \% & 0 \%\end{array}$

Figure 7. continued 


\begin{tabular}{|c|c|c|c|c|c|c|c|c|c|c|c|c|c|c|c|c|c|c|c|c|c|c|c|c|}
\hline Unclassified & $0 \%$ & $0 \%$ & $0 \%$ & $1 \%$ & $1 \%$ & $1 \%$ & $0 \%$ & $0 \%$ & $0 \%$ & $0 \%$ & $0 \%$ & $0 \%$ & $0 \%$ & $0 \%$ & $0 \%$ & $1 \%$ & $1 \%$ & $1 \%$ & $0 \%$ & $0 \%$ & $0 \%$ & $0 \%$ & $0 \%$ & $0 \%$ \\
\hline \multicolumn{25}{|l|}{ Acidobacteria } \\
\hline Bryobacter & $1 \%$ & $1 \%$ & $1 \%$ & $1 \%$ & $1 \%$ & $1 \%$ & $1 \%$ & $1 \%$ & $1 \%$ & $0 \%$ & $0 \%$ & $1 \%$ & $1 \%$ & $3 \%$ & $1 \%$ & $0 \%$ & $0 \%$ & $0 \%$ & $0 \%$ & $0 \%$ & $0 \%$ & $0 \%$ & $1 \%$ & $1 \%$ \\
\hline OLB17 & $0 \%$ & $0 \%$ & $0 \%$ & $0 \%$ & $0 \%$ & $0 \%$ & $0 \%$ & $0 \%$ & $0 \%$ & $0 \%$ & $1 \%$ & $0 \%$ & $0 \%$ & $0 \%$ & $0 \%$ & $0 \%$ & $0 \%$ & $0 \%$ & $0 \%$ & $0 \%$ & $0 \%$ & $0 \%$ & $0 \%$ & $1 \%$ \\
\hline \multicolumn{25}{|l|}{ Armatimonadetes } \\
\hline Armatimonadetes unclassified & $3 \%$ & $1 \%$ & $1 \%$ & $0 \%$ & $0 \%$ & $0 \%$ & $0 \%$ & $0 \%$ & $0 \%$ & $0 \%$ & $0 \%$ & $0 \%$ & $2 \%$ & $1 \%$ & $1 \%$ & $1 \%$ & $0 \%$ & $0 \%$ & $0 \%$ & $0 \%$ & $0 \%$ & $0 \%$ & $0 \%$ & $0 \%$ \\
\hline \multicolumn{25}{|l|}{ Gemmatimonadetes } \\
\hline S0134 terrestrial group & $0 \%$ & $0 \%$ & $1 \%$ & $1 \%$ & $0 \%$ & $0 \%$ & $0 \%$ & $0 \%$ & $0 \%$ & $0 \%$ & $0 \%$ & $0 \%$ & $0 \%$ & $1 \%$ & $1 \%$ & $0 \%$ & $0 \%$ & $0 \%$ & $0 \%$ & $0 \%$ & $0 \%$ & $0 \%$ & $0 \%$ & $0 \%$ \\
\hline Unclassified & $0 \%$ & $0 \%$ & $0 \%$ & $0 \%$ & $0 \%$ & $0 \%$ & $0 \%$ & $0 \%$ & $0 \%$ & $0 \%$ & $0 \%$ & $0 \%$ & $0 \%$ & $0 \%$ & $0 \%$ & $0 \%$ & $0 \%$ & $0 \%$ & $0 \%$ & $1 \%$ & $2 \%$ & $1 \%$ & $0 \%$ & $1 \%$ \\
\hline \multicolumn{25}{|l|}{ Patescibacteria } \\
\hline Ca. Peregrinibacteria & $0 \%$ & $0 \%$ & $0 \%$ & $0 \%$ & $0 \%$ & $0 \%$ & $0 \%$ & $0 \%$ & $0 \%$ & $1 \%$ & $1 \%$ & $2 \%$ & $0 \%$ & $0 \%$ & $0 \%$ & $0 \%$ & $0 \%$ & $0 \%$ & $0 \%$ & $1 \%$ & $1 \%$ & $2 \%$ & $2 \%$ & $0 \%$ \\
\hline \multicolumn{25}{|l|}{ Spirochaetes } \\
\hline Turneriella & $0 \%$ & $0 \%$ & $0 \%$ & $1 \%$ & $1 \%$ & $1 \%$ & $0 \%$ & $0 \%$ & $0 \%$ & $0 \%$ & $0 \%$ & $0 \%$ & $0 \%$ & $0 \%$ & $0 \%$ & $0 \%$ & $0 \%$ & $0 \%$ & $0 \%$ & $0 \%$ & $0 \%$ & $0 \%$ & $0 \%$ & $0 \%$ \\
\hline Unclassified & $2 \%$ & $0 \%$ & $0 \%$ & $0 \%$ & $0 \%$ & $0 \%$ & $0 \%$ & $0 \%$ & $0 \%$ & $0 \%$ & $0 \%$ & $0 \%$ & $3 \%$ & $0 \%$ & $0 \%$ & $0 \%$ & $0 \%$ & $0 \%$ & $0 \%$ & $0 \%$ & $0 \%$ & $0 \%$ & $0 \%$ & $0 \%$ \\
\hline \multicolumn{25}{|l|}{ Verrucomicrobia } \\
\hline Ca. Xiphinematobacter & $0 \%$ & $1 \%$ & $0 \%$ & $0 \%$ & $0 \%$ & $0 \%$ & $0 \%$ & $0 \%$ & $0 \%$ & $0 \%$ & $0 \%$ & $0 \%$ & $0 \%$ & $1 \%$ & $0 \%$ & $0 \%$ & $0 \%$ & $0 \%$ & $0 \%$ & $0 \%$ & $0 \%$ & $0 \%$ & $0 \%$ & $0 \%$ \\
\hline Opitutaceae unclassified & $0 \%$ & $0 \%$ & $0 \%$ & $0 \%$ & $0 \%$ & $0 \%$ & $0 \%$ & $0 \%$ & $0 \%$ & $0 \%$ & $0 \%$ & $1 \%$ & $0 \%$ & $0 \%$ & $0 \%$ & $0 \%$ & $0 \%$ & $0 \%$ & $0 \%$ & $0 \%$ & $0 \%$ & $0 \%$ & $0 \%$ & $0 \%$ \\
\hline \multicolumn{25}{|l|}{ Kiritimatiellaeota } \\
\hline $113 B 434$ & $0 \%$ & $0 \%$ & $0 \%$ & $0 \%$ & $0 \%$ & $0 \%$ & $0 \%$ & $0 \%$ & $0 \%$ & $0 \%$ & $0 \%$ & $0 \%$ & $0 \%$ & $1 \%$ & $1 \%$ & $0 \%$ & $0 \%$ & $0 \%$ & $0 \%$ & $0 \%$ & $0 \%$ & $0 \%$ & $0 \%$ & $0 \%$ \\
\hline \multicolumn{25}{|l|}{ Cyanobacteria } \\
\hline Obscuribacterales unclassified & $0 \%$ & $0 \%$ & $0 \%$ & $0 \%$ & $0 \%$ & $0 \%$ & $0 \%$ & $0 \%$ & $0 \%$ & $0 \%$ & $0 \%$ & $1 \%$ & $0 \%$ & $0 \%$ & $0 \%$ & $0 \%$ & $0 \%$ & $0 \%$ & $0 \%$ & $0 \%$ & $0 \%$ & $0 \%$ & $0 \%$ & $0 \%$ \\
\hline \multicolumn{25}{|l|}{ Bacteria_unclassified } \\
\hline Unclassified & $1 \%$ & $1 \%$ & $1 \%$ & $1 \%$ & $0 \%$ & $0 \%$ & $0 \%$ & $1 \%$ & $1 \%$ & $1 \%$ & $1 \%$ & $0 \%$ & $1 \%$ & $1 \%$ & $1 \%$ & $1 \%$ & $0 \%$ & $0 \%$ & $0 \%$ & $1 \%$ & $1 \%$ & $1 \%$ & $1 \%$ & $1 \%$ \\
\hline \multicolumn{25}{|l|}{ Other genera } \\
\hline & $16 \%$ & $14 \%$ & $15 \%$ & $18 \%$ & $14 \%$ & $12 \%$ & $11 \%$ & $10 \%$ & $13 \%$ & $13 \%$ & $15 \%$ & $11 \%$ & $15 \%$ & $15 \%$ & $15 \%$ & $13 \%$ & $12 \%$ & $10 \%$ & $13 \%$ & $10 \%$ & $11 \%$ & $12 \%$ & $12 \%$ & $12 \%$ \\
\hline
\end{tabular}

Figure 7. Evolution of the microbial community structure in both SBRs throughout a 12 month experimental period (phase I: months 1-4; phase II: months 5-8; phase III: months 9-10; and phase IV: months 11-12; month 1 is December 2018). The analysis was performed at the genus level for SBR1 (A) and SBR2 (B). The operational taxonomic units (OTUs) with percentages $\geq 1 \%$ in at least one sample were retrieved. The

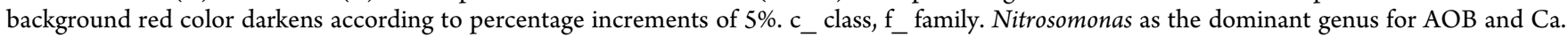
Kuenenia as the dominant genus for AnAOB are indicated in red color.

teobacteria] (9\% in SBR1 and $8 \%$ in SBR2), Nitrosomonas [Betaproteobacteria] (5\% in SBR1 and 7\% in SBR2), and the uncultured genus PHOS-H36 [Bacteroidetes, class Ignavibacteria] (6\% in SBR1 and $7 \%$ in SBR2) (Figure 6). The nonidentification of members of the phylum Chlorobi, which have commonly been reported in anammox-related studies, could be justified by the recent reclassification of Ignavibacteria as members of Bacteriodetes instead of Chlorobi as suggested by Hiras et al. ${ }^{54}$ and according to sequence identification using the Silva database taxonomy.

The main genus responsible for the aerobic oxidation of ammonium to nitrite is Nitrosomonas europaea. This species is represented by 11 OTUs accounting for $99.99 \%$ of the sequences corresponding to AOB, with OTU4 being clearly dominant since it accounted for $91.42 \%$ of the sequences, while the remaining $0.01 \%$ of the $\mathrm{AOB}$ sequences were identified as Nitrosomonas stercoris (OTU1469). No nitriteoxidizing bacteria (NOB) were detected in the bioreactors during the whole experimental period. The dominant genus performing the anammox reaction was Ca. Kuenenia (Ca. Kuenenia stuttgartiensis at the species level). In this regard, Ca. $K$. stuttgartiensis was already the dominant species in the anammox sludge used as inoculum ( $28 \%$ of the relative abundance in the sludge collected in the anammox reactor from the landfill site) and remained as the dominant AnAOB species in the PNA SBRs throughout the experimental period (initial percentages of ca. $16 \%$, which increased up to maximum values of $29 \%$ in SBR1 (month 12 ) and $28 \%$ in SBR2 (months 5, 6, and 8)). In phase II, the consolidation of the granular PNA process resulted in steady AnAOB relative abundances above 21\% (SBR1) and 25\% (SBR2), while AOB decreased along time (i.e., generally speaking, the AnAOB/ AOB ratio progressively increased in both SBRs during this phase), coinciding with the increase of the NCRs in the bioreactors (Figure S6). Subsequently, when the metal ions were dosed during phase III, relative abundances for AnAOB declined progressively, while percentages for $A O B$ remained constant (SBR1-Ca) or behaved oppositely than AnAOB $(\mathrm{SBR} 2-\mathrm{Mg}$ ) (i.e., in this case, the $\mathrm{AnAOB} / \mathrm{AOB}$ ratio decreased in both SBRs). The raise in the abundance of AnAOB (and AOB) in SBR1 in the last sample available for phase IV (day 343) might be linked to the stimulus induced by the purge of sludge applied on day 285 and the growth of new granules not accumulated at the bottom of the bioreactor yet. Ca. K. stuttgartiensis is known to have a high affinity for nitrite and to tolerate well moderate salinity conditions, ${ }^{56}$ factors that could justify the selection of this species within the bioreactors. Other anammox genera were also detected in the PNA SBRs but at much lower levels, i.e., Ca. Brocadia $(\leq 0.11 \%)$, especially in phase I, and Ca. Anammoximicrobium ( $\leq 0.05 \%)$.

Besides the anammox phylotype, several other bacterial genera showed an increase in relative abundance throughout the experimental period, including bacteria able to become involved in denitrification processes but also in other processes not directly related to the $\mathrm{N}$-cycle. More precisely, for instance, Arenimonas increased from 4 to $18 \%$ in SBR1 and from 5 to $25 \%$ in SBR2 during phase I, returning to lower percentages later on (Figure 7). This was the main heterotrophic genus found in the bioreactors, which includes representatives able to produce and degrade EPS. ${ }^{35}$ The relative abundance of the uncultured bacterium PHOS-HE36 also increased progressively along time (i.e., from $<0.2 \%$ at the beginning of phase I to $\geq 13 \%$ by the end of phase III). This versatile genus, frequently associated with a polymer-degrading function, has been reported to survive under anoxic and anaerobic conditions, and it has been found in different types of wastewater treatment systems. ${ }^{57-60}$ Its high percentage in phases III and IV might be related to the deviation observed for the nitrate-to-ammonium reaction ratio during this period (Figure 1C). Ca. Accumulibacter phosphatis, which is the typical PAO frequently found in EBPR systems, and which has previously been postulated as HAP producer in granular PNA reactors despite being available in small percentages (e.g., ca. $0.4 \%$ in Gonzalez-Martinez et $\mathrm{al}^{46}$ ), was not found within the microbial community of both SBRs under study. Yet, other bacterial genera potentially capable of behaving as $\mathrm{PAOs}^{61}$ were identified in these bioreactors, e.g., Dechloromonas, Tetrasphaera, Gemmatimonas (each genus averaging the same 


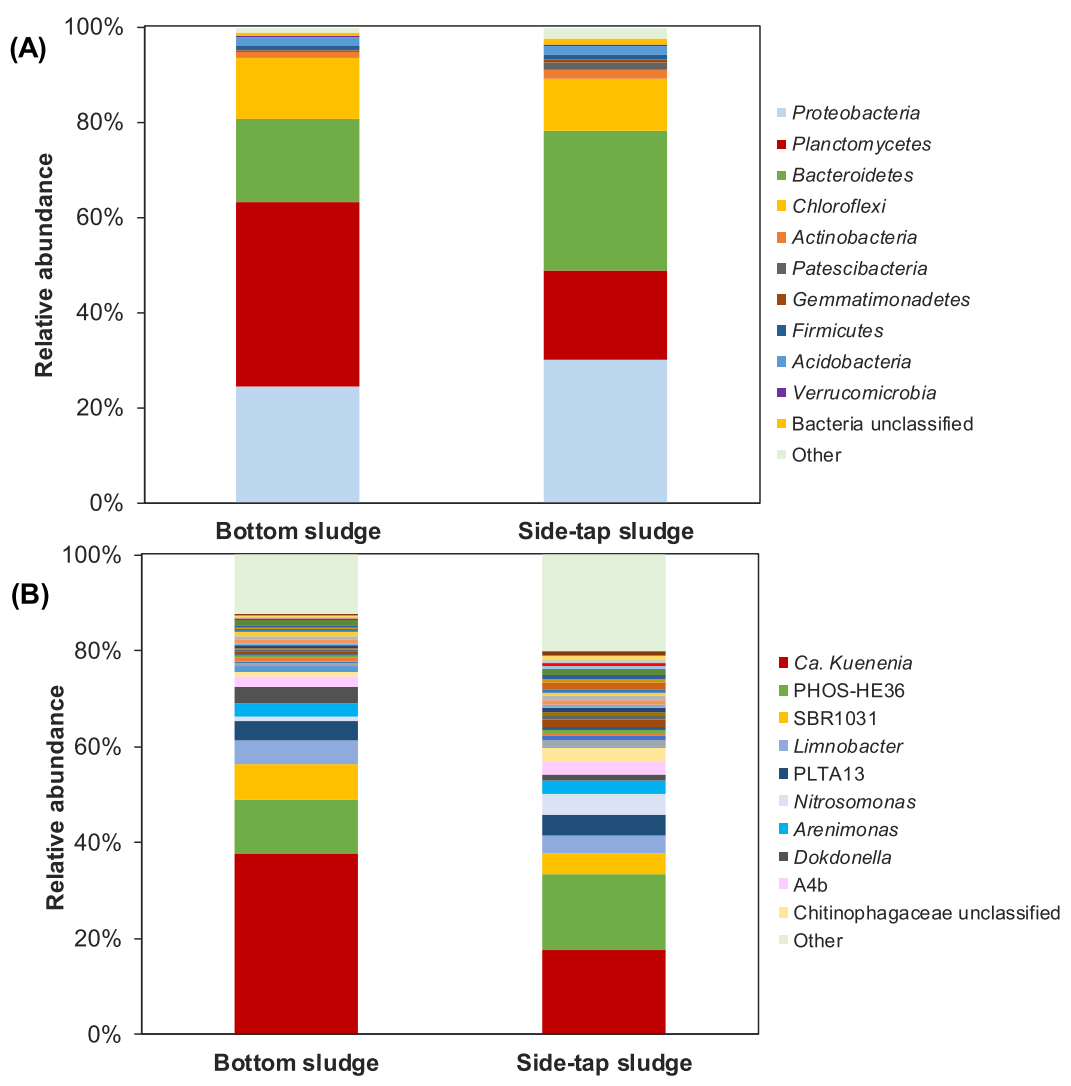

Figure 8. Comparison of the microbial community structure in the granular sludge collected from SBR1 (phase III, month 10, day 285) taking into account samples harvested from the bottom tap (bottom sludge) and from the solids' sampling tap (side-tap sludge). Analysis performed at the phylum (A) and genus (B) levels. The operational taxonomic units (OTUs) with relative abundance < $1 \%$ were grouped as "other".

percentage regardless of the bioreactor assessed within the range $0.01-0.10 \%$ ), and Pseudomonas (which averaged $0.12 \%$ in SBR1-maximum values reached in phase III, but $0.03 \%$ in SBR2). In addition, uncultured cyanobacteria belonging to the order Obscuribacterales were also detected throughout all of the operational period in both reactors ranging from 0.1 to $0.7 \%$ and from 0.1 to $0.4 \%$ in SBR1 and SBR2, respectively. These abundances are slightly higher than the $0.1 \%$ reported for Ca. Obscuribacter phosphatis, ${ }^{61}$ which has been recently suggested to play a putative role in EBPR-based processes. Overall, the microbial community analysis reveals that other uncultured bacteria beyond Ca. A. phosphatis, including uncultured representatives, might play an important role in $\mathrm{P}$ biomineralization as HAP. This result needs to be further addressed in the future by gene expression studies aiming to unravel the identity and the physiological properties of the key organisms favoring HAP formation, which, in turn, will help in enhancing the engineering of the process.

Microbial Community Structure in Different Types of Granules from SBR1. Granules collected from the bottom tap of SBR1 showed a higher density than those collected from the solids' sampling tap (Figure S1) due to the higher mineral content in the core (see the section "Composition of the Mineral Phosphate Formed”). To assess the microbial community structure of both types of granules, sludge samples were taken from both taps in phase III (month 10, day 285). The results showed that the granules from the bottom doubled the relative abundance in anammox taxons (38\%) with respect to the granules from the side tap (18\%). Also, the percentages for Nitrosomonas were lower for the bottom granules (1 vs $4 \%$ for the side-tap granules) (Figure 8). This fact would help in justifying the permanent loss of anammox activity observed after the purge of sludge carried out on day 285 , and it is in line with other studies ${ }^{12,62,63}$ stating that the larger (and denser) granules, besides settling faster, harbor larger anoxic volumes, since the oxygen penetration depth is expected to be the same regardless of the size of the granule, which results in favorable conditions for the growth of AnAOB. Otherwise, Bacteroidetes showed a higher relative abundance in the granules from the side tap (29\%) than in the granules from the bottom (18\%), which agrees with the previously formulated hypothesis that representatives of this phylum contribute significantly to the formation and maturation of the granules. Overall, these results suggest that by an intensive harvesting of the P-rich granules accumulated at the bottom of the SBR1, part of the anammox activity was lost, and the system tended to be more prone to the accumulation of nitrite.

Additional Prospects. In granular sludge PNA systems, the accumulation of HAP for its subsequent valorization as raw material sounds advantageous due to the feasibility of long sludge retention times inside the bioreactor and, once the sludge purged, the possibility for long-term storage before final use. Granules with a mineral HAP core are quite stable and can easily be dehydrated. In contrast to the polyP formed in EBPR systems, where purge of excess sludge needs to be managed appropriately to avoid issues with secondary $\mathrm{P}$ release, the precipitated phosphate salts such as HAP are much more stable. However, this study has proved that, although HAP crystallization is compatible with the biological reactions of the PNA process, formation of the mineral phase inside the 
granule can significantly reduce the biological activity in the long term. In this regard, a compromise will be needed to balance the interest of extracting HAP-rich granules from the bioreactor, achieving satisfactory $\mathrm{N}$-removal performance. The regular purge of the densest granules formed within the bioreactor would be helpful, avoiding long periods between purges and then proceed to massive sludge discharge. Alternative reactor configurations to SBRs such as the airlift systems have demonstrated good performance regarding the combined PNA + HAP process, reaching higher process rates. $^{23}$ On the other hand, the N/P ratio of the wastewater will have an impact on the process, affecting the amount of sludge produced and its composition. The phosphate content in urban sidestream centrates is variable, depending on factors such as the procedure used to achieve $\mathrm{P}$ removal in the mainstream (biological vs chemical). Values are normally higher when EBPR-based processes are involved owing to the hydrolysis of the polyP in the anaerobic digester and the consequent release of orthophosphate. For P-rich wastewater, phosphate could finally be precipitated chemically as $\mathrm{CaP}$ by adding a Ca source. ${ }^{64}$ If the precipitation takes place at high $\mathrm{pH}$ values, outside the optimal $\mathrm{pH}$ range for bioprocesses such as PNA, that will make segregated downstream $P$ precipitation necessary. Yet, the high removal of inorganic carbon usually achieved through the PNA process is supposed to facilitate the recovery of phosphate as $\mathrm{CaP}$ and help reduce the use of chemicals to modify the $\mathrm{pH}$. According to van der Kooij et al., ${ }^{65}$ optimized $\mathrm{P}$ recovery from sidestream centrate in urban WWTPs will result in modest recovery efficiencies of 3-8\% of all $\mathrm{P}$ excreted by humans. Other $\mathrm{P}$ entering the treatment plant but not recoverable from the centrate will partly be contained in the treated effluent (ca. 20\%) and mostly in the dewatered digested sludge (ca. 50-70\%). Yet, although $\mathrm{P}$ recovery through crystallization from water lines may appear to offer a limited contribution to resolve the global $\mathrm{P}$ issues, at a more local scale, such a recovery strategy may offer WWTPs the opportunity of contributing to the creation of more sustainable communities while protecting the environment.

\section{CONCLUSIONS}

Feasibility for inducing mineralization of dissolved orthophosphate from urban sidestream centrate in an anammox system running under low-intensity aeration was confirmed. Mineral cores formed inside the granules were mostly composed of HAP (material recoverable as precipitated phosphate salt). The addition of a Ca source helped in enhancing the P-uptake efficiency from the water phase. Yet, the high mineral content of the sludge and its excessive purge from the bioreactor limited the microbial activity in the long term. The densest granules, accumulated at the bottom of the bioreactor, were the richest in HAP but also contained the highest percentages of AnAOB. An operational compromise will thus be needed taking into account the interest of extracting P-rich granules from the system but also the achievement of a satisfactory bioprocess performance.

\section{ASSOCIATED CONTENT}

\section{s) Supporting Information}

The Supporting Information is available free of charge at https://pubs.acs.org/doi/10.1021/acssuschemeng.0c08036.

Experimental setup (Figure S1); chemical analysis, biological tests, and calculations (Table S1, centrate characteristics; Figures S2, microscope observations; Figure S3, XRD pattern); and microbial community analysis (Table S2, $\alpha$-diversity indexes; Figure S4, rarefraction curves; Figure S5, NMDS plots; Figure S6, relative abundances for $\mathrm{AOB}$ and $\mathrm{AnAOB}$ together with NCR) (PDF)

\section{AUTHOR INFORMATION}

\section{Corresponding Author}

Albert Magrí - LEQUIA, Institute of the Environment, University of Girona, E-17003 Girona, Catalonia, Spain; - orcid.org/0000-0002-6993-0746; Phone: +34 972419 542; Email: albert.magri@udg.edu, albert.magri@ gmail.com

\section{Authors \\ Emma Company - LEQUIA, Institute of the Environment, University of Girona, E-17003 Girona, Catalonia, Spain; (1) orcid.org/0000-0001-7528-9679 \\ Frederic Gich - gEMM, Institute of Aquatic Ecology, University of Girona, E-17003 Girona, Catalonia, Spain; (1) orcid.org/0000-0002-0941-634X \\ Jesús Colprim - LEQUIA, Institute of the Environment, University of Girona, E-17003 Girona, Catalonia, Spain; (1) orcid.org/0000-0002-6000-069X}

Complete contact information is available at:

https://pubs.acs.org/10.1021/acssuschemeng.0c08036

\section{Notes}

The authors declare no competing financial interest.

\section{ACKNOWLEDGMENTS}

This research was conducted in the framework of the research project DigesTake (COMRDI16-1-0061) funded by ACCIÓ (Generalitat de Catalunya) within the program Comunitat RIS3CAT Aigua. The group LEQUIA (http://www.lequia. udg.edu/) is recognized as a consolidated research group by the Catalan Government (2017-SGR-1552). The authors thank the collaboration of the staff from the company OMSSACEDE in charge of operating the Terri WWTP (Sunsi Ferrer) and the laboratory work carried out by the students Anastasya Kravtchenko, Guillem Coma, and Mireia Pulido as part of their bachelor's theses at the University of Girona.

\section{ACRONYMS AND ABBREVIATIONS}

ACP amorphous calcium phosphate $\left(\mathrm{Ca}_{3}\left(\mathrm{PO}_{4}\right)_{2} \cdot x \mathrm{H}_{2} \mathrm{O}\right)$ anammox anaerobic ammonium oxidation

AnAOB anaerobic ammonium-oxidizing bacteria (anammox bacteria)

AOB ammonium-oxidizing bacteria

$\mathrm{CaP} \quad$ calcium phosphates

DW dry weight

EBPR enhanced biological phosphorus removal

EC electrical conductivity

EGSB expanded granular sludge bed

EPS extracellular polymeric substances

EU European Union

HAP hydroxyapatite $\left(\mathrm{Ca}_{10}\left(\mathrm{PO}_{4}\right)_{6}(\mathrm{OH})_{2}\right)$

IAP ion activity product

ICP inductively coupled plasma

IL-AR internal loop airlift reactor

$K_{\text {sp }} \quad$ solubility product constant 
MAP magnesium ammonium phosphate hexahydrate (struvite, $\mathrm{MgNH}_{4} \mathrm{PO}_{4} \cdot 6 \mathrm{H}_{2} \mathrm{O}$ )

$\mathrm{MgP}$ magnesium phosphates

MS mass spectrometry

MW mineral fraction weight

NCBI National Center for Biotechnology Information

NCE nitrogen conversion efficiency

NCR nitrogen conversion rate

NLR nitrogen loading rate

NMDS nonmetric multidimensional scaling

NOB nitrite-oxidizing bacteria

NRE nitrogen removal efficiency

NRR nitrogen removal rate

OCP octacalcium phosphate $\left(\mathrm{Ca}_{8} \mathrm{H}_{2}\left(\mathrm{PO}_{4}\right)_{6} \cdot 5 \mathrm{H}_{2} \mathrm{O}\right)$

OES optical emission spectrometry

OTU operational taxonomic unit

PAO polyphosphate accumulating organism

PLR phosphorus loading rate

PN partial nitritation

PNA PN-anammox

PUE phosphorus uptake efficiency

PUR phosphorus uptake rate

rRNA ribosomal ribonucleic acid

SBR sequencing batch reactor

SNCR specific nitrogen conversion rate

SNRR specific nitrogen removal rate

SPUR specific phosphorus uptake rate

SI saturation index, $\log _{10}\left(\mathrm{IAP} / \mathrm{K}_{\mathrm{sp}}\right)$

SRA sequence read archive

SVI sludge volume index

TCP tricalcium phosphate $\left(\mathrm{Ca}_{3}\left(\mathrm{PO}_{4}\right)_{2}\right)$

TSS total suspended solids

VSS volatile suspended solids

WWTP wastewater treatment plant

XRD X-ray diffraction

\section{REFERENCES}

(1) Cordell, D.; White, S. Peak phosphorus: clarifying the key issues of a vigorous debate about long-term phosphorus security. Sustainability 2011, 3, 2027-2049.

(2) Gilbert, N. The disappearing nutrient. Nature 2009, 461, 716718.

(3) EU. Communication from the Commission to the European Parliament, the Council, the European Economic and Social Committee and the Committee of the Regions on the 2017 List of Critical Raw Materials for the EU, $\operatorname{COM}(2017)$ 490; European Commission: Brussels, Belgium, 2017. https://ec.europa.eu/transparency/regdoc/ rep/1/2017/EN/COM-2017-490-F1-EN-MAIN-PART-1.PDF (last accessed Dec 18, 2020).

(4) Carpenter, S. R. Phosphorus control is critical to mitigating eutrophication. Proc. Natl. Acad. Sci. U.S.A. 2008, 105, 11039-11040.

(5) Egle, L.; Rechberger, H.; Zessner, M. Overview and description of technologies for recovering phosphorus from municipal wastewater. Resour., Conserv. Recycl. 2015, 105, 325-346.

(6) Magrí, A.; Carreras-Sempere, M.; Biel, C.; Colprim, J. Recovery of phosphorus from waste water profiting from biological nitrogen treatment: upstream, concomitant or downstream precipitation alternatives. Agronomy 2020, 10, No. 1039.

(7) Römer, W.; Steingrobe, B. Fertilizer effect of phosphorus recycling products. Sustainability 2018, 10, No. 1166.

(8) Law, K. P.; Pagilla, K. R. Phosphorus recovery by methods beyond struvite precipitation. Water Environ. Res. 2018, 90, 840-850.

(9) Wang, L.; Nancollas, G. H. Calcium orthophosphates: crystallization and dissolution. Chem. Rev. 2008, 108, 4628-4669.
(10) Lackner, S.; Gilbert, E. M.; Vlaeminck, S. E.; Joss, A.; Horn, H.; van Loosdrecht, M. C. M. Full-scale partial nitritation/anammox experiences - An application survey. Water Res. 2014, 55, 292-303.

(11) Rittmann, B. E.; McCarty, P. L. Environmental Biotechnology: Principles and Applications; McGraw Hill Education: Chennai, India, 2012.

(12) Strous, M.; Heijnen, J. J.; Kuenen, J. G.; Jetten, M. S. M. The sequencing batch reactor as a powerful tool for the study of slowly growing anaerobic ammonium-oxidizing microorganisms. Appl. Microbiol. Biotechnol. 1998, 50, 589-596.

(13) Rodriguez-Garcia, G.; Frison, N.; Vázquez-Padín, J. R.; Hospido, A.; Garrido, J. M.; Fatone, F.; Bolzonella, D.; Moreira, M. T.; Feijoo, G. Life cycle assessment of nutrient removal technologies for the treatment of anaerobic digestion supernatant and its integration in a wastewater treatment plant. Sci. Total Environ. 2014, 490, 871-879.

(14) Schaubroeck, T.; De Clippeleir, H.; Weissenbacher, N.; Dewulf, J.; Boeckx, P.; Vlaeminck, S. E.; Wett, B. Environmental sustainability of an energy self-sufficient sewage treatment plant: Improvements through DEMON and co-digestion. Water Res. 2015, 74, 166-179.

(15) Vlaeminck, S. E.; De Clippeleir, H.; Verstraete, W. Microbial resource management of one-stage partial nitritation/anammox. Microb. Biotechnol. 2012, 5, 433-448.

(16) Vangsgaard, A. K.; Mauricio-Iglesias, M.; Gernaey, K. V.; Sin, G. Development of novel control strategies for single-stage autotrophic nitrogen removal: A process oriented approach. Comput. Chem. Eng. 2014, 66, 71-81.

(17) Winkler, M. K. H.; Kleerebezem, R.; Kuenen, J. G.; Yang, J.; van Loosdrecht, M. C. M. Segregation of biomass in cyclic anaerobic/ aerobic granular sludge allows the enrichment of anaerobic ammonium oxidizing bacteria at low temperatures. Environ. Sci. Technol. 2011, 45, 7330-7337.

(18) Simoes, F.; Vale, P.; Stephenson, T.; Soares, A. The role of $\mathrm{pH}$ on the biological struvite production in digested sludge dewatering liquors. Sci. Rep. 2018, 8, No. 7225.

(19) Johansson, S.; Ruscalleda, M.; Colprim, J. Phosphorus recovery through biologically induced precipitation by partial nitritationanammox granular biomass. Chem. Eng. J. 2017, 327, 881-888.

(20) Ma, H.; Guo, Y.; Qin, Y.; Li, Y.-Y. Nutrient recovery technologies integrated with energy recovery by waste biomass anaerobic digestion. Bioresour. Technol. 2018, 269, 520-531.

(21) Zhang, Y.; Ma, H.; Lin, L.; Cao, W.; Ouyang, T.; Li, Y.-Y. Enhanced simultaneous nitrogen and phosphorus removal performance by anammox-HAP symbiotic granules in the attached film expanded bed reactor. ACS Sustainable Chem. Eng. 2018, 6, 1098910998.

(22) Ma, H.; Xue, Y.; Zhang, Y.; Kobayashi, T.; Kubota, K.; Li, Y.-Y. Simultaneous nitrogen removal and phosphorus recovery using an anammox expanded reactor operated at $25^{\circ} \mathrm{C}$. Water Res. 2020, 172, No. 115510.

(23) Guo, Y.; Li, Y.-Y. Hydroxyapatite crystallization-based phosphorus recovery coupling with the nitrogen removal through partial nitritation/anammox in a single reactor. Water Res. 2020, 187, No. 116444.

(24) Mañas, A.; Pocquet, M.; Biscans, B.; Sperandio, M. Parameters influencing calcium phosphate precipitation in granular sludge sequencing batch reactor. Chem. Eng. Sci. 2012, 77, 165-175.

(25) Cunha, J. R.; Tervahauta, T.; van der Weijden, R. D.; Temmink, H.; Hernández-Leal, L.; Zeeman, G.; Buisman, C. J. N. The effect of bioinduced increased $\mathrm{pH}$ on the enrichment of calcium phosphate in granules during anaerobic treatment of black water. Environ. Sci. Technol. 2018, 52, 13144-13154.

(26) Anfruns, A.; Gabarró, J.; Gonzalez-Olmos, R.; Puig, S.; Balaguer, M. D.; Colprim, J. Coupling anammox and advanced oxidation-based technologies for mature landfill leachate treatment. J. Hazard. Mater. 2013, 258-259, 27-34.

(27) Gustafsson, J. P. Visual MINTEQ ver. 3.1; KTH, 2018. https:// vminteq.lwr.kth.se/ (last accessed Dec 18th, 2020). 
(28) Schwarzenbeck, N.; Borges, J. M.; Wilderer, P. A. Treatment of dairy effluents in an anaerobic granular sludge batch reactor. Appl. Microbiol. Biotechnol. 2005, 66, 711-718.

(29) Kończak, B.; Karcz, J.; Miksch, K. Influence of calcium, magnesium, and iron ions on aerobic granulation. Appl. Biochem. Biotechnol. 2014, 174, 2910-2918.

(30) Sajjad, M.; Kim, K. S. Studies on the interactions of $\mathrm{Ca}^{2+}$ and $\mathrm{Mg}^{2+}$ with EPS and their role in determining the physicochemical characteristics of granular sludges in SBR system. Process Biochem. 2015, 50, 966-972.

(31) Hou, X.; Liu, S.; Zhang, Z. Role of extracellular polymeric substance in determining the high aggregation ability of anammox sludge. Water Res. 2015, 75, 51-62.

(32) Chini, A.; Hollas, C. E.; Bolsan, A. C.; Venturin, B.; Bonassa, G.; Cantão, M. E.; Ibelli, A. M. G.; Antes, F. G.; Kunz, A. Process performance and anammox community diversity in a deammonification reactor under progressive nitrogen loading rates for swine wastewater treatment. Bioresour. Technol. 2020, 311, No. 123521.

(33) Wang, S.; Wang, L.; Deng, L.; Zheng, D.; Zhang, Y.; Jiang, Y.; Yang, H.; Lei, Y. Performance of autotrophic nitrogen removal from digested piggery wastewater. Bioresour. Technol. 2017, 241, 465-472.

(34) Vázquez-Padín, J. R.; Pozo, M. J.; Jarpa, M.; Figueroa, M.; Franco, A.; Mosquera-Corral, A.; Campos, J. L.; Méndez, R. Treatment of anaerobic sludge digester effluents by the CANON process in an air pulsing SBR. J Hazard. Mater. 2009, 166, 336-341.

(35) Joss, A.; Salzgeber, D.; Eugster, J.; König, R.; Rottermann, K.; Burger, S.; Fabijan, P.; Leumann, S.; Mohn, J.; Siegrist, H. Full-scale nitrogen removal from digester liquid with partial nitritation and anammox in one SBR. Environ. Sci. Technol. 2009, 43, 5301-5306.

(36) Jeanningros, Y.; Vlaeminck, S. E.; Kaldate, A.; Verstraete, W.; Graveleau, L. Fast start-up of a pilot-scale deammonification sequencing batch reactor from an activated sludge inoculum. Water Sci. Technol. 2010, 61, 1393-1400.

(37) Sperandio, M.; Pambrun, V.; Paul, E. Simultaneous removal of $\mathrm{N}$ and $\mathrm{P}$ in a SBR with production of valuable compounds: application to concentrated wastewaters. Water Sci. Technol. 2008, $58,859-864$.

(38) Ren, T.-T.; Liu, L.; Sheng, G.-P.; Liu, X.-W.; Yu, H.-Q.; Zhang, M.-C.; Zhu, J.-R. Calcium spatial distribution in aerobic granules and its effects on granule structure, strength and bioactivity. Water Res. 2008, 42, 3343-3352.

(39) Lin, Y. M.; Lotti, T.; Sharma, P. K.; van Loosdrecht, M. C. M. Apatite accumulation enhances the mechanical property of anammox granules. Water Res. 2013, 47, 4556-4566.

(40) Xing, B.-S.; Guo, Q.; Yang, G.-F.; Zhang, Z.-Z.; Li, P.; Guo, L.X.; Jin, R.-C. The properties of anaerobic ammonium oxidation (anammox) granules: Roles of ambient temperature, salinity and calcium concentration. Sep. Purif. Technol. 2015, 147, 311-318.

(41) Bayo, J.; López-Castellanos, J.; Martínez-García, R.; Alcolea, A.; Lardín, C. Hydrocyclone as a cleaning device for anaerobic sludge digesters in a wastewater treatment plant. J. Cleaner Prod. 2015, 87, 550-557.

(42) Yuan, Z.; Pratt, S.; Batstone, D. J. Phosphorus recovery from wastewater through microbial processes. Curr. Opin. Biotechnol. 2012, $23,878-883$.

(43) Schipper, W. J.; Klapwijk, A.; Potjer, B.; Rulkens, W. H.; Temmink, B. G.; Kiestra, F. D. G.; Lijmbach, A. C. M. Phosphate recycling in the phosphorus industry. Environ. Technol. 2001, 22, 1337-1345.

(44) EU. Regulation (EU) 2019/1009 of the European Parliament and of the Council of 5 June 2019 Laying Down Rules on the Making Available on the Market of EU Fertilising Products and Amending Regulations (EC) No 1069/2009 and (EC) No 1107/2009 and Repealing Regulation (EC) No 2003/2003; European Parliament and the Council of the European Union, 2019; pp L 170/1-L 170/114. http://data.europa.eu/eli/reg/2019/1009/oj (last accessed Dec 18, 2020).

(45) Connan, R.; Dabert, P.; Khalil, H.; Bridoux, G.; Béline, F.; Magrí, A. Batch enrichment of anammox bacteria and study of the underlying microbial community dynamics. Chem. Eng. J. 2016, 297, 217-228.

(46) Gonzalez-Martinez, A.; Rodriguez-Sanchez, A.; Rivadeneyra, M. A.; Rivadeneyra, A.; Martin-Ramos, D.; Vahala, R.; Gonzalez-Lopez, J. 16S rRNA gene-based characterization of bacteria potentially associated with phosphate and carbonate precipitation from a granular autotrophic nitrogen removal bioreactor. Appl. Microbiol. Biotechnol. 2017, 101, 817-829.

(47) Akaboci, T. R. V.; Gich, F.; Ruscalleda, M.; Balaguer, M. D.; Colprim, J. Assessment of operational conditions towards mainstream partial nitritation-anammox stability at moderate to low temperature: Reactor performance and bacterial community. Chem. Eng. J. 2018, $350,192-200$.

(48) van Niftrik, L.; Jetten, M. S. M. Anaerobic ammonium-oxidizing bacteria: unique microorganisms with exceptional properties. Microbiol. Mol. Biol. Rev. 2012, 76, 585-596.

(49) Speth, D. R.; in 't Zandt, M. H.; Guerrero-Cruz, S.; Dutilh, B. E.; Jetten, M. S. M. Genome-based microbial ecology of anammox granules in a full-scale wastewater treatment system. Nat. Commun. 2016, 7, No. 11172.

(50) Lawson, C. E.; Wu, S.; Bhattacharjee, A. S.; Hamilton, J. J.; McMahon, K. D.; Goel, R.; Noguera, D. R. Metabolic network analysis reveals microbial community interactions in anammox granules. Nat. Commun. 2017, 8, No. 15416.

(51) Zhao, Y.; Liu, S.; Jiang, B.; Feng, Y.; Zhu, T.; Tao, H.; Tang, X.; Liu, S. Genome-centered metagenomics analysis reveals the symbiotic organisms possessing ability to cross-feed with anammox bacteria in anammox consortia. Environ. Sci. Technol. 2018, 52, 11285-11296.

(52) Kindaichi, T.; Yuri, S.; Ozaki, N.; Ohashi, A. Ecophysiological role and function of uncultured Chloroflexi in an anammox reactor. Water Sci. Technol. 2012, 66, 2556-2561.

(53) Chu, Z.-r.; Wang, K.; Li, X.-k.; Zhu, M.-t.; Yang, L.; Zhang, J. Microbial characterization of aggregates within a one-stage nitritationanammox system using high-throughput amplicon sequencing. Chem. Eng. J. 2015, 262, 41-48.

(54) Hiras, J.; Wu, Y.-W.; Eichorst, S. A.; Simmons, B. A.; Singer, S. W. Refining the phylum Chlorobi by resolving the phylogeny and metabolic potential of the representative of a deeply branching, uncultivated lineage. ISME J. 2016, 10, 833-845.

(55) Quast, C.; Pruesse, E.; Yilmaz, P.; Gerken, J.; Schweer, T.; Yarza, P.; Peplies, J.; Glöckner, F. O. The SILVA ribosomal RNA gene database project: improved data processing and web-based tools. Nucleic Acids Res. 2012, 41, D590-D596.

(56) Zhang, L.; Okabe, S. Ecological niche differentiation among anammox bacteria. Water Res. 2020, 171, No. 115468.

(57) Dabert, P.; Sialve, B.; Delgenès, J.-P.; Moletta, R.; Godon, J.-J. Characterisation of the microbial $16 \mathrm{~S}$ rDNA diversity of an aerobic phosphorus-removal ecosystem and monitoring of its transition to nitrate respiration. Appl. Microbiol. Biotechnol. 2001, 55, 500-509.

(58) Koenig, A.; Zhang, T.; Liu, L.-H.; Fang, H. H. P. Microbial community and biochemistry process in autosulfurotrophic denitrifying biofilm. Chemosphere 2005, 58, 1041-1047.

(59) Qiao, S.; Kawakubo, Y.; Cheng, Y.; Nishiyama, T.; Fujii, T.; Furukawa, K. Identification of bacteria coexisting with anammox bacteria in an upflow column type reactor. Biodegradation 2009, 20, $117-124$.

(60) Zhu, J.; Chen, L.; Zhang, Y.; Zhu, X. Revealing the anaerobic acclimation of microbial community in a membrane bioreactor for coking wastewater treatment by Illumina Miseq sequencing. $J$. Environ. Sci. 2018, 64, 139-148.

(61) Stokholm-Bjerregaard, M.; McIlroy, S. J.; Nierychlo, M.; Karst, S. M.; Albertsen, M.; Nielsen, P. H. A critical assessment of the microorganisms proposed to be important to enhanced biological phosphorus removal in full-scale wastewater treatment systems. Front. Microbiol. 2017, 8, No. 718.

(62) Bagchi, S.; Lamendella, R.; Strutt, S.; Van Loosdrecht, M. C. M.; Saikaly, P. E. Metatranscriptomics reveals the molecular mechanism of large granule formation in granular anammox reactor. Sci. Rep. 2016, 6, No. 28327. 
(63) Luo, J.; Chen, H.; Han, X.; Sun, Y.; Yuan, Z.; Guo, J. Microbial community structure and biodiversity of size-fractionated granules in a partial nitritation-anammox process. FEMS Microbiol. Ecol. 2017, 93, No. fix021.

(64) Monballiu, A.; Desmidt, E.; Ghyselbrecht, K.; Meesschaert, B. Phosphate recovery as hydroxyapatite from nitrified UASB effluent at neutral $\mathrm{pH}$ in a CSTR. J. Environ. Chem. Eng. 2018, 6, 4413-4422.

(65) van der Kooij, S.; van Vliet, B. J. M.; Stomph, T. J.; Sutton, N. B.; Anten, N. P. R.; Hoffland, E. Phosphorus recovered from human excreta: A socio-ecological-technical approach to phosphorus recycling. Resour., Conserv. Recycl. 2020, 157, No. 104744. 